HYDROBORATION, A BRIEF HISTORICAL REVIEW THROUGH MECHANISTIC VIEWS, PART I: ALKYL- AND ARYL-SUBSTITUTED OLEFINS, AS ADDITIONSUBSTRATES; THE ORGANIC CHEMISTRY NOTEBOOK, N 15

\section{HIDROBORACIÓN, UNA BREVE REVISIÓN HISTÓRICA A TRAVÉS DE VISTAS MECANICISTAS, PARTE I: OLEFINAS ALIFÁTICAS Y AROMÁTICAS COMO SUSTRATOS DE ADICIÓN; EL CUADERNO DE QUÍMICA ORGÁNICA, Nº 15}

Received 09112019

Accepted 04192020

Published 04302020

Vol. 37, No.1, pp. 46-63, Ene./Abr.2020

Revista Boliviana de Química

37(1), 46-63, Jan./Apr. 2020

Bolivian Journal of Chemistry

DOI : $10.34098 / 2078-3949.37 .1 .7$

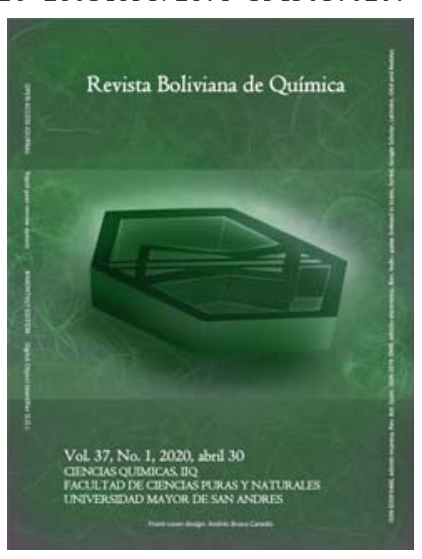

Short review

Peer-reviewed

José A. Bravo ${ }^{1, *}$, José L. Vila ${ }^{2}$

${ }^{1}$ Natural Product Laboratory, Phytochemistry, Chemical Sciences Department, Instituto de Investigaciones Químicas IIQ, Facultad de Ciencias Puras y Naturales FCPN, Universidad Mayor de San Andres UMSA, P.O. Box 303, Calle Andrés Bello s/n, Ciudad Universitaria Cota Cota, phone +59122792238, La Paz, Bolivia, jabravo@umsa.bo, joseabravo@outlook.com, www.umsa.bo

\begin{abstract}
${ }^{2}$ Natural Product Laboratory, Synthesis and Hemisynthesis, Chemical Sciences Department, Instituto de Investigaciones Químicas IIQ, Facultad de Ciencias Puras y Naturales FCPN, Universidad Mayor de San Andres UMSA, P.O. Box 303, Calle Andrés Bello s/n, Ciudad Universitaria Cota Cota, phone +59122772269 , La Paz, Bolivia, jlvila@umsa.bo, joselu62@hotmail.com, www.umsa.bo
\end{abstract}

Keywords: Organic Chemistry, Addition reaction, Multiple bonds, Organoboranes, Hydroboration, Mechanisms of Reactions.

Palabras clave: Química orgánica, Reacción de adición, Enlaces múltiples, Organoboranos, Hidroboración, Mecanismos de reacción.

\title{
ABSTRACT
}

The Organic Chemistry Notebook Series, a Didactical Approach, is the series designed with educational purposes in the organic synthesis field. With the present paper we add to a total of fourteen contributions so far in the series.

This series of studies is designed to help students when getting started in the synthesis subject. The method of learning includes many fully and explicitly designed reactions step by step. The best manner to understand a synthesis is by means of graphical views, in this case, the ones proposed by the authors of this series, and, when in most of the cases they are accompanied by illustrative comments that describe the graphical mechanistic proposals and add some criteria deduced from the different mechanistic steps. During the past 14 chapters we have taken a series of reactions compiled by W. Carruthers in 'Some modern methods of organic synthesis', and we have proposed didactical and mechanistic views for them. Now we are boarding another important compiling source in the synthesis studies: 'Advanced Organic Chemistry, Part B: Reaction and Synthesis' by Francis A. Carey and 
Richard J. Sundberg. This theme is included in the chapter "Electrophilic additions to carbon-carbon multiple bonds", and references therein.

*Corresponding author: jabravo@umsa.bo, joseabravo@outlook.com

\section{RESUMEN}

La Serie de Cuadernos de Química Orgánica, un Enfoque Didáctico, es la serie diseñada con fines educativos en el campo de la síntesis orgánica. Con el presente trabajo agregamos un total de quince contribuciones hasta ahora en la serie.

Esta serie de estudios está diseñada para ayudar a los estudiantes cuando se inician en el tema de síntesis. El método de aprendizaje incluye muchas reacciones diseñadas de forma completa y explícita paso a paso. La mejor manera de comprender una síntesis es mediante vistas gráficas, en este caso, las propuestas por los autores de esta serie y, cuando en la mayoría de los casos, van acompañadas de comentarios ilustrativos que describen las propuestas gráficas mecanicistas y agregan algunos criterios deducidos de los diferentes pasos mecanicistas. Durante los 14 capítulos anteriores, hemos tomado una serie de reacciones compiladas por W. Carruthers en "Algunos métodos modernos de síntesis orgánica", y hemos propuesto puntos de vista didácticos y mecanicistas. Ahora abordamos otra fuente importante en los estudios de síntesis: "Química orgánica avanzada, Parte B: Reacción y síntesis" de Francis A. Carey y Richard J. Sundberg". Este tema se incluye en el capítulo "Adiciones electrofílicas a los enlaces múltiples carbono-carbono" en el texto mencionado y referencias incluidas.

\section{INTRODUCTION}

Due to lack of knowledge of classical mechanisms, students experiment emptiness when comprehending a determined synthesis found in the literature. Since a mechanistic proposal is naturally mandatory for a rational explanation of products emerging from a synthesis, we offer the present series theming on mechanistic approaches on several published syntheses. As academics we are committed with the didactics and we have designed a series of articles exposing mechanistic theoretical proposals, articles have a character of short review. The present contribution: Hydroboration, a brief historical review through mechanistic views, part I: alkyl- and aryl-substituted olefins, as addition-substrates, The Organic Chemistry Notebook, $\mathrm{N}^{0} 15$, that refers to regioselectivity considerations, is the fifteenth study in the series: "The Organic Chemistry Notebook Series, a Didactical Approach" [1-14].

\section{REVIEW OF REACTIONS, MECHANISTIC THEORETICAL PROPOSALS, DISCUSSION}

\section{Hydroboration of olefins}

Hydroboration is a good method in many synthesis reactions employing electron-rich compounds as substrate, namely alkenes and alkynes [15]. Boron as borane $\mathrm{BH}_{3}$ is a Lewis acid with a free orbital suitable for rooming an electron pair. Borane is available as a dimer, $\mathrm{B}_{2} \mathrm{H}_{6}$, with the boron atoms bridged by two of the six hydrogens between them [15]. Due to its Lewis acid nature (Figure 1), boron interacts with Lewis bases such as oxygen, nitrogen or sulphur in ethers, tertiary amines and sulfides, $\mathrm{R}_{2} \mathrm{O}^{+}-\mathrm{BH}_{3}, \mathrm{R}_{3} \mathrm{~N}^{+}-\mathrm{BH}_{3}, \mathrm{R}_{2} \mathrm{~S}^{+}-\mathrm{BH}_{3}$ [15], see boron hybridation's changement when borane overlaps with Lewis bases (Figure 2).

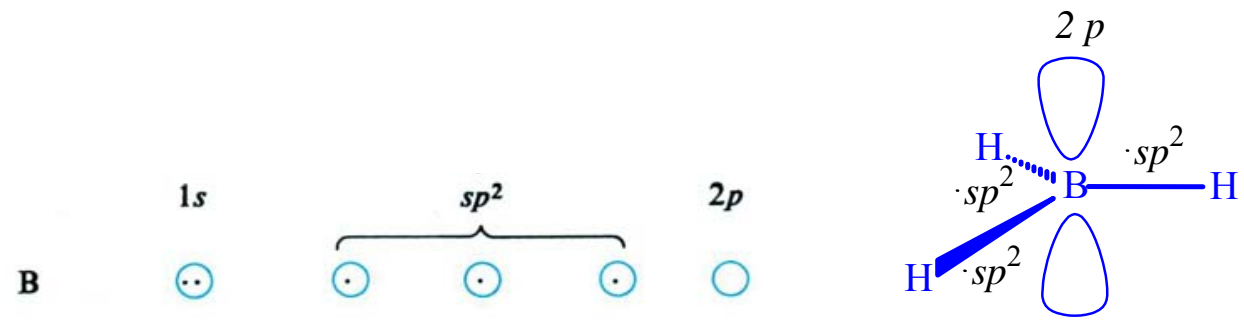

Figure 1. Boron electronic structure, borane structure 


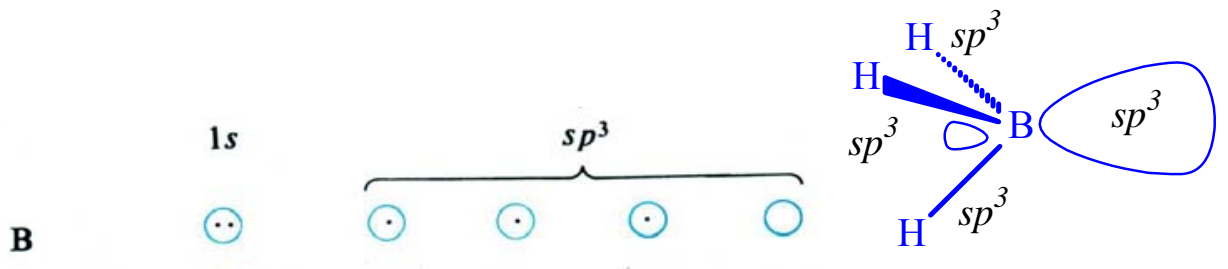

Figure 2. Boron hybridation's changement when borane overlaps with Lewis bases

Using THF as solvent or DMS, the addition of borane over most alkenes is immediate [15], a reaction known as hydroboration. Hydroboration is stereospecific and very regioselective [15]. Steric and electronic effects are involved in the addition of borane and they favor the attack over the carbon the less substituted [15]. Since borane reacts with alkenes until completion of the hydride substitution in $\mathrm{BH}_{3}$ and their replacement by the adding on three alkene molecules to give a trialkyl borane, the less substituted carbon is chosen by boron in order to avoid steric hindrance when adding the second and the third alkenic residue, e.g. the addition of $\mathrm{BH}_{3}$ to 2-methyl-1-propene, where atom 1 is preferred over atom 2 for the new B-C bond [15], see Figure 3. This behavior gives this reaction its regioselective quality [15]. The minor option of addition of the boron atom to the carbon with the most steric hindrance represents severe nonbonded repulsions, see Figure 4.
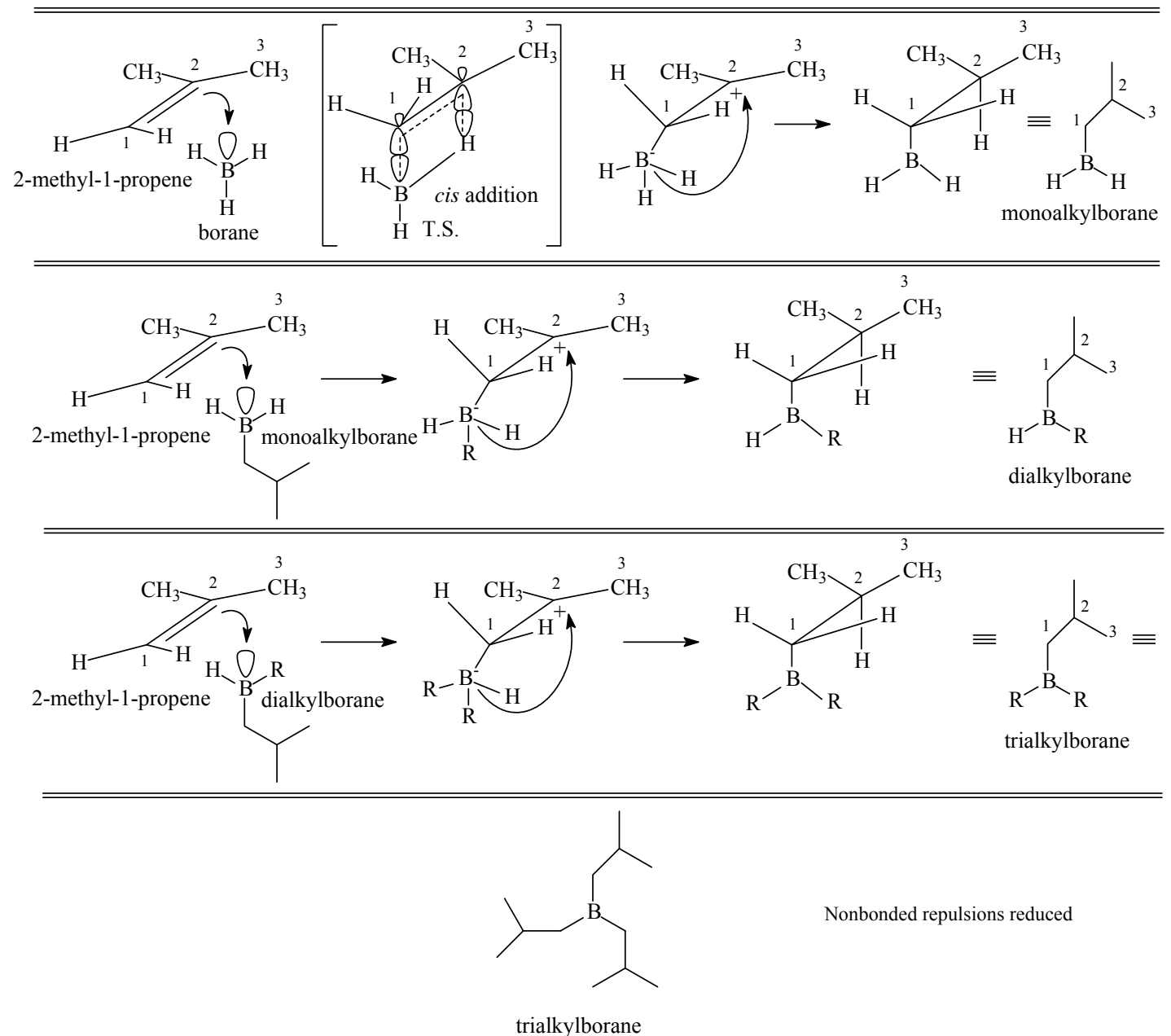

Figure 3. Hydroboration of 2-methyl-1-propene, boron's addition over the carbon with the less steric hindrance. Nonbonded repulsions reduced [15]. Theoretical mechanistic proposals by the authors 


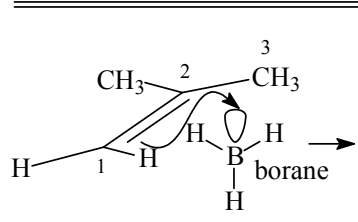

2-methyl-1-propene

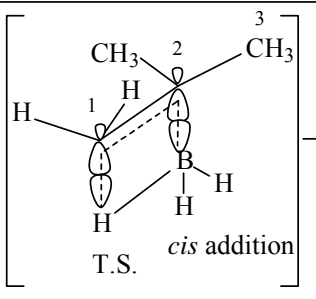

T.S

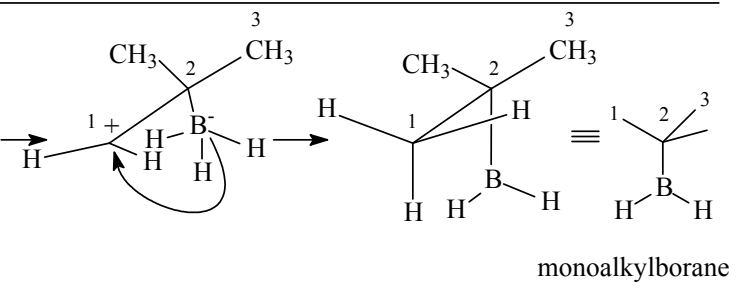

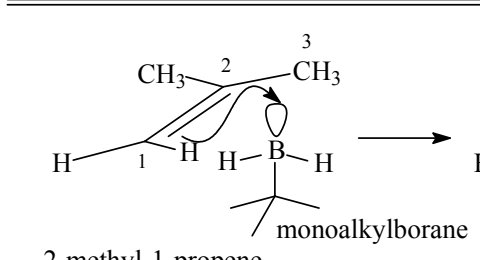

2-methyl-1-propene

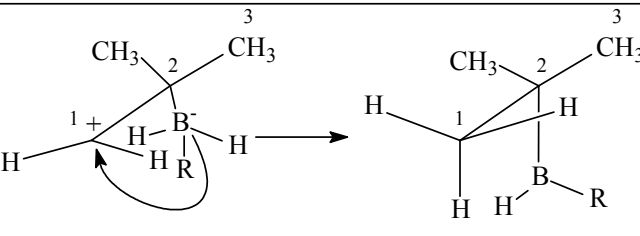

$\mathrm{H} \quad \mathrm{H}^{\prime}{ }_{\mathrm{R}}$

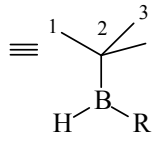

dialkylborane
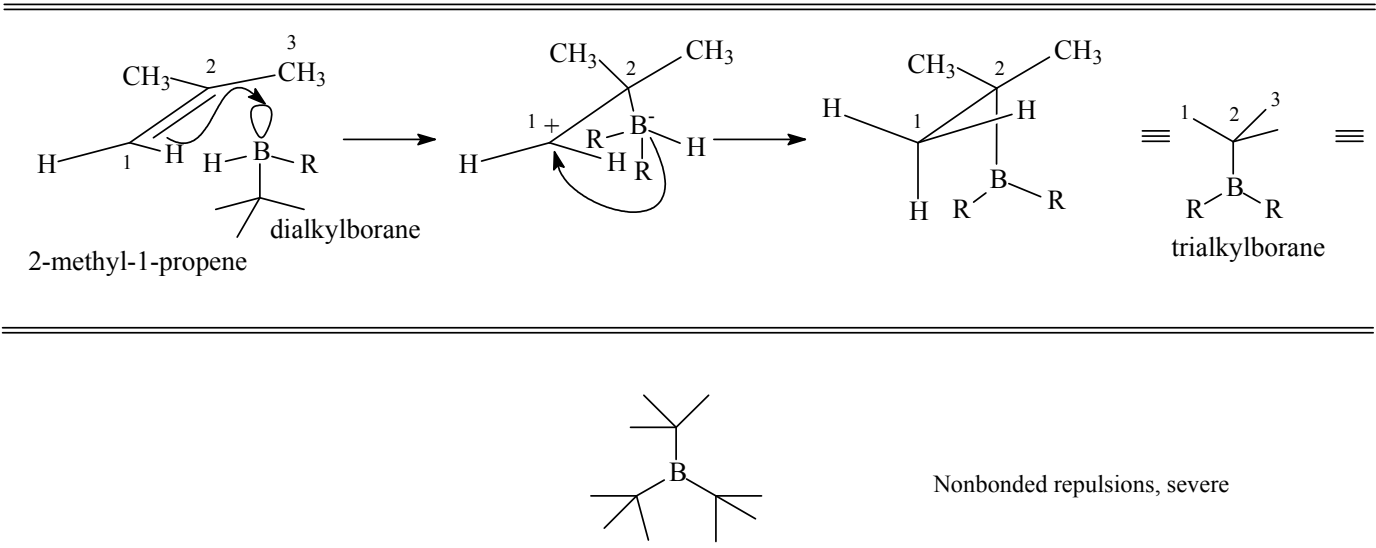

Nonbonded repulsions, severe

trialkylborane

Figure 4. Minor hydroboration of 2-methyl-1-propene, boron's addition over the carbon with the most steric hindrance. Nonbonded repulsions, severe [15]. Theoretical mechanistic proposals by the authors

The regioselectivity can be improved by the use of some mono or dialkylboranes instead borane itself (disiamylborane [DAB, 15,16], thexylborane [TB, 15,17], 9-BBN [15,18]). While diborane shows a 94\% of regioselectivity in hydroboration of 1-hexene, this increases to $99 \%$ when using chloroborane-dimethyl sulfide $[15,19,20]$, or DAB $[15,16]$ or thexylchloroborane-dimethyl sulfide $[15,21]$, and $99.9 \%$ if $9-\mathrm{BBN}$ is used $[15,18]$, but it's equal (94\%) if TB is used [15,17]. When the substrate of the hydroboration is 2-methyl-1-butene diborane gives $99 \%$, chloroborane-dimethyl sulfide 99.5\%, thexylchloroborane-dimethyl sulfide 97\%, and 9-BBN 99.8\%. Changing the substrate to 4-methyl-2-pentene diborane gave 57\%, DAB 97\%, TB 66\%, thexylchloroboranedimethyl sulfide $99 \%$, and 9 -BBN $99.8 \%$. Finally, [15] styrene as substrate gave a regioselectivity of $80 \%$ (diborane), 98\% (chloroborane-dimethyl sulfide, and DAB), 95\% (TB), 99\% (thexylchloroborane-dimethyl sulfide), and $98.5 \%(9-\mathrm{BBN})$. These alkylboranes can be prepared by hydroboration of the corresponding alkene, the degree of alkylation of borane comes out from stoichiometric control [15]. See Figure 5.

\section{Comments}

The fact of adding alkyl substituents on the boron atom implies obviously an increase of the steric hindrance at the moment of interaction between the reagent and the substrate olefin. This tool makes more difficult the interaction with the most hindered carbon and accelerates the rate of attacking the less hindered sterically carbon. 
REVISTA BOLIVIANA DE QUÍMICA

ISSN 0250-5460 Rev. Bol. Quim. Paper edition

ISSN 2078-3949 Rev. boliv. quim. Electronic edition

José A. Bravo et José L. Vila RBQ VoI. 37, No.1, pp. 46-63, 2020

$2\left(\mathrm{CH}_{3}\right)_{2} \mathrm{C}=\mathrm{CHCH}_{3}$

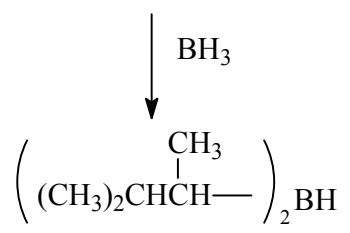

disiamylborane DAB bis(3-methyl-3-butyl)borane<smiles>CC(C)C(CC(C)(C)C)C(C)(C)C</smiles>

thexylborane TB<smiles>C=CCCCC</smiles><smiles>C=C(C)CC</smiles>

1-Hexene<smiles>C=Cc1ccccc1</smiles>

Styrene

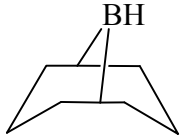

9-BBN

1,1,2-trimethylpropylborane 9-borabicyclo[3.3.1]nonane

Figure 5. Regioselectivity, as shown by the use of many alkene substrates and varied borane alkyl derivatives [15,17]

As shown above in Figures 3 and 4, the borane or its derivative in hydroboration follows a syn (cis) stereospecific addition on the alkene [15]. The transition state (T.S.) involves a four center adduct with simultaneous bonding to B and $\mathrm{H}$ [15]. This atoms' spatial position makes possible the formation of the new bonds $\mathrm{B}-\mathrm{C}$ and $\mathrm{H}-\mathrm{C}$, as being formed in the same side of the double bond [15]. A previous to the transition-state-step is the interaction of the two electrons of the bond $\pi$ and the empty orbital $p$ of the boron $s p^{2}$, see Figure $6[15,17]$.

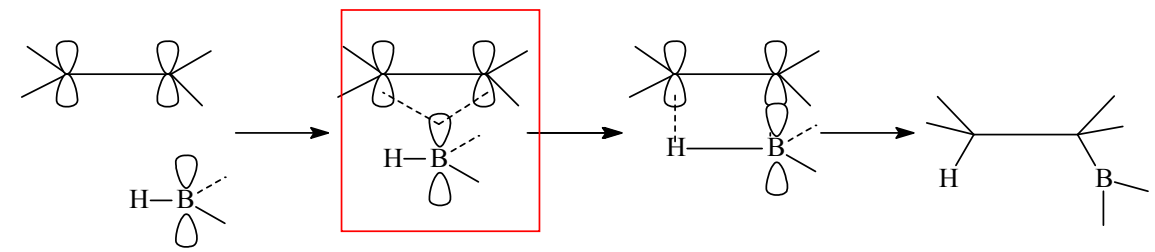

Figure 6. Previous to the transition-state-step is the interaction of the two electrons of the bond $\pi$ and the empty orbital $p$ of the boron $\mathrm{sp}^{2}[15]$

Diborane is gaseous, but soluble in ether after dissociating into monomeric borane as etherate in varied ethers. Ether acts as catalyst in the addition reaction because of its ability of dissociating diborane [17]. The ethereal nature as solvent is not determining in the direction of addition in the hydroboration of styrene [17]. This means that the solvent does not participate actively in the transition state. On the other hand, the hydroborating agent $\left(\mathrm{LiBH}_{4} \mathrm{Or} \mathrm{Na}\right.$ $\mathrm{BH}_{4}$ or $\mathrm{B}_{2} \mathrm{H}_{6}$ ) does not make much difference in the direction of the addition either. Temperature variations didn't influence the addition direction [17]. As a general result in the distribution of boron over the double bond is from 94 to $98 \%$ in the same direction, or the less hindered carbon, in most of the cases. Indicated yields were of $90 \%$ or higher. The majority of olefins proceed in the reaction until the trialkyl borane, however, there are exceptions with the more hindered olefins that can reach the monoalkyl or dialkylborane stage [17]. The addition to styrene $(20 \% \alpha)$ or $p$-chlorosytrene $(35 \% \alpha)$ is different [17]. Styrene was chosen for studying the influence of temperature, solvent and hydroboring agent with regard to the direction of addition. A small increase in temperature produced an increase in the percentage of the $\alpha$-derivative [17]. Hydroboration was also surveyed under the scope of the effect of the structure of the olefin involved in five groups, alkyl monosubstituted terminal olefins (I), alkyl disubstituted terminal olefins (II), alkyl disubstituted internal olefins (III), alkyl trisubstituted internal olefins (IV), $p$-substituted styrenes (V) [17]. The results pointed out the preferred anti-Markownikoff type of addition. Group I with alkyl substitutents, linear or branched gave $93-94 \%$ of addition of the boron to the terminal carbon. If the substituent includes somehow phenyl, the boron addition to the terminal carbon is between 80 to $90 \%$. Group II presents a $99 \%$ of the primary alkylborane due to two substituents that exert steric compression on the more unsaturated carbon. Group III like 2-

\footnotetext{
Downloadable from: Revista Boliviana $50 \quad$ de Química. Volumen 37 №1. Año 2020

http://www.bolivianchemistryjournal.org, http://www.scribd.com/bolivianjournalofchemistry
} 
José A. Bravo et José L. Vila RBQ VoI. 37, No.1, pp. 46-63, 2020

pentene and 2-hexene undergo addition of the boron in almost equal proportions to both sides of the double bond. Slight variation is seen from cis to trans isomers. Group IV shows addition results with boron added to the secondary carbon in about $98 \%$ and only $2 \%$ for the tertiary compound. Group V included results derived from the relative strong influence of the phenyl group over addition on the double bond on styrene.

\section{Hydroboration of alkyl-substituted olefins}

The directive effects of the similar structural features of different alkyl-substituted olefins during addition of hydrogen and boron to the double bond were studied [17].

\section{Alkyl-monosubstituted terminal olefins $\mathrm{RCH}=\mathrm{CH}_{2}$}

Straight-chain terminal olefins like 1-butene (Figure 7), 1-pentene and 1-hexene (Figure 8) give preferably the addition of boron to the terminal carbon in a $93-94 \%$ ( 6 to $7 \%$ for the secondary alkyl boron derivative) [17].
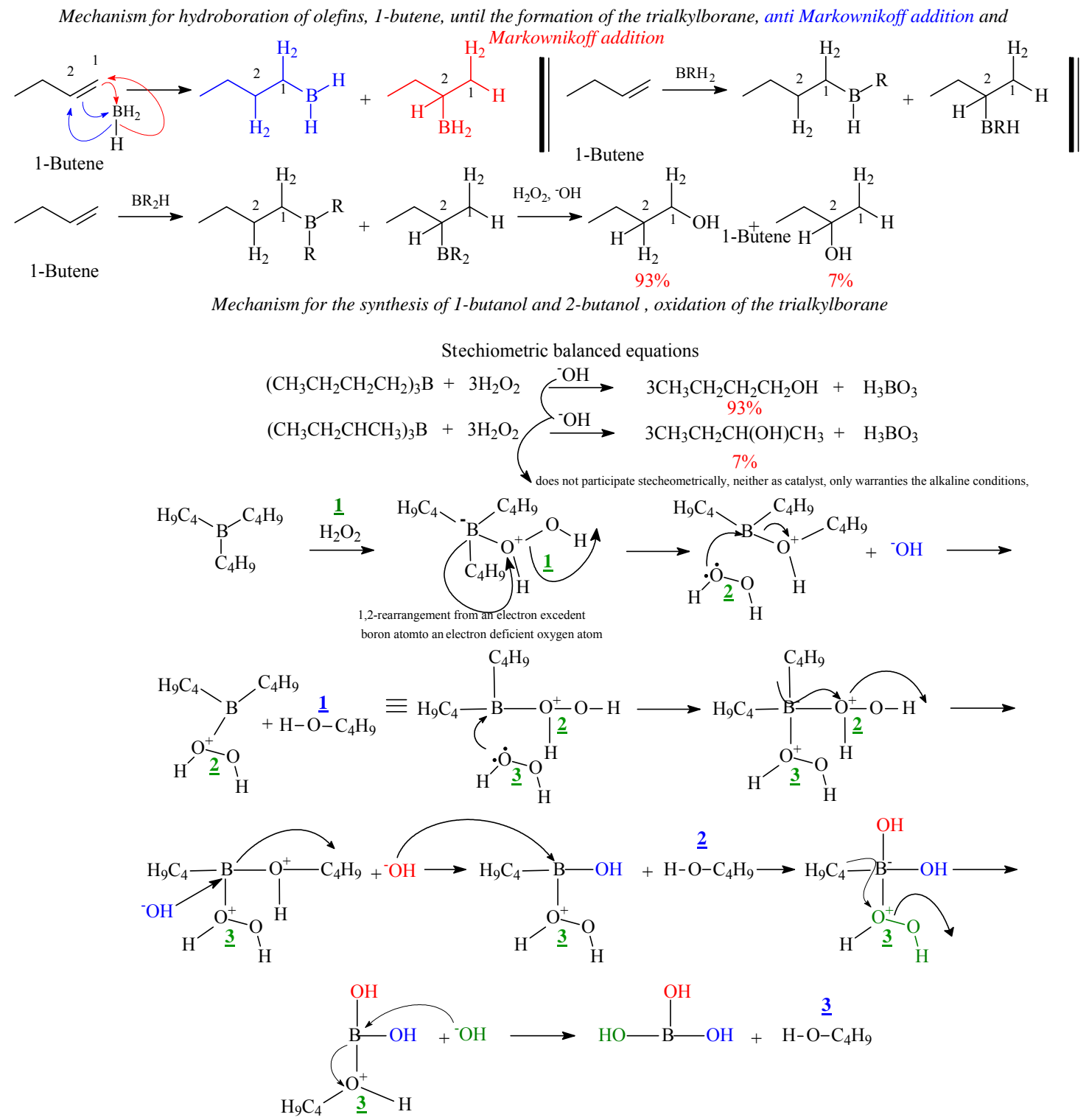

Figure 7. Hydroboration of 1-butene until completion of reaction obtaining the corresponding trialkylborane, oxidation until obtaining of the alcohol [17]. Theoretical mechanistic views proposals by the authors. 
José A. Bravo et José L. Vila RBQ VoI. 37, No.1, pp. 46-63, 2020

The alkyl branching makes not much difference in the boron distribution as shown with the use of 3-methyl-1butene, 3,3-dimethyl-1-butene (Figure 9) and 4,4-dimethyl-1-pentene [17] (Figure 10).
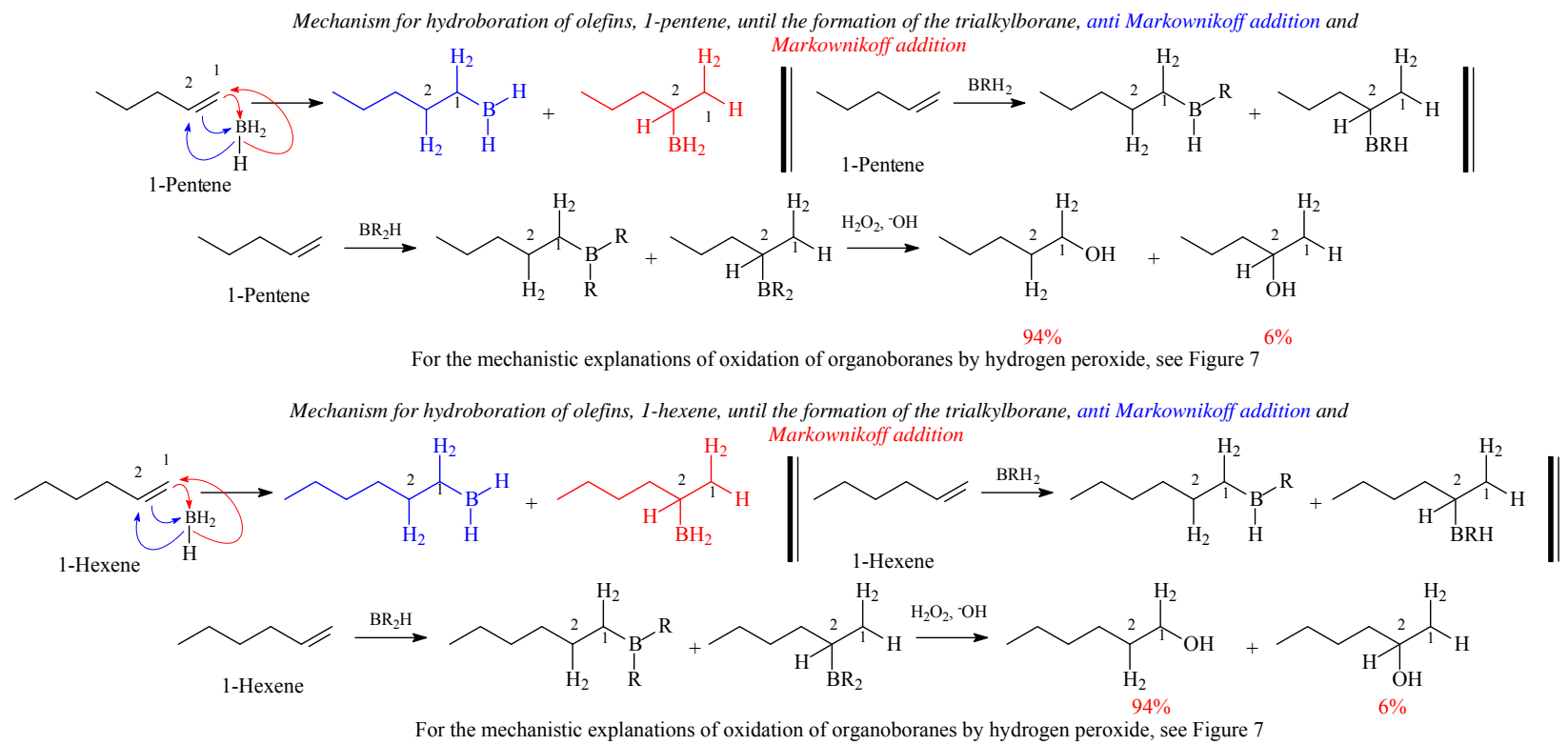

Figure 8. Hydroboration of 1-pentene and 1-hexene until completion of reaction obtaining the corresponding trialkylborane, oxidation until obtaining of the corresponding alcohol [17]. Theoretical mechanistic views proposals by the authors

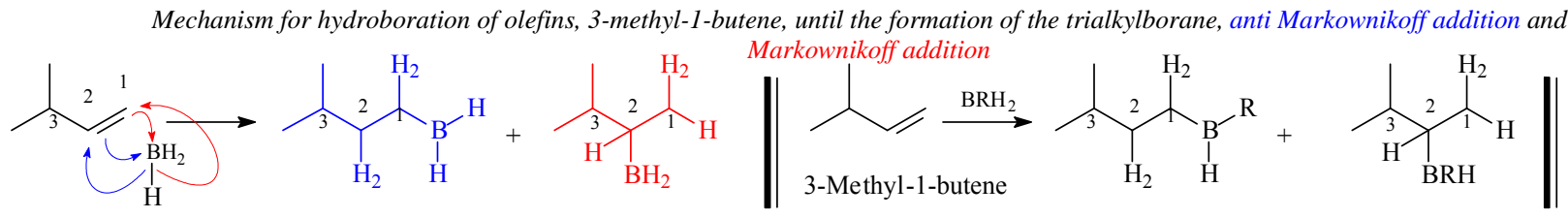

3-Methyl-1-butene

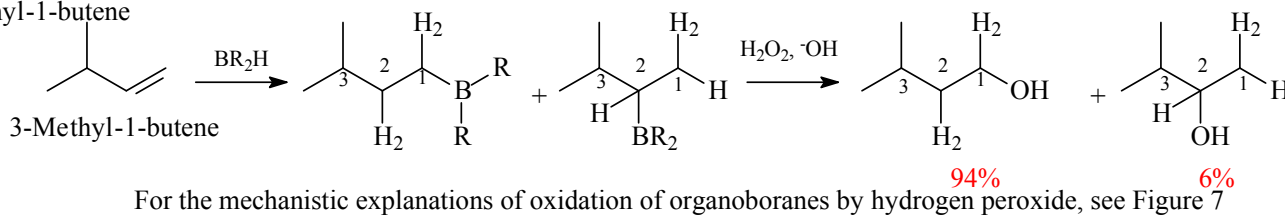

Mechanism for hydroboration of olefins, 3,3-dimethyl-1-butene, until the formation of the trialkylborane, anti Markownikoff addition and

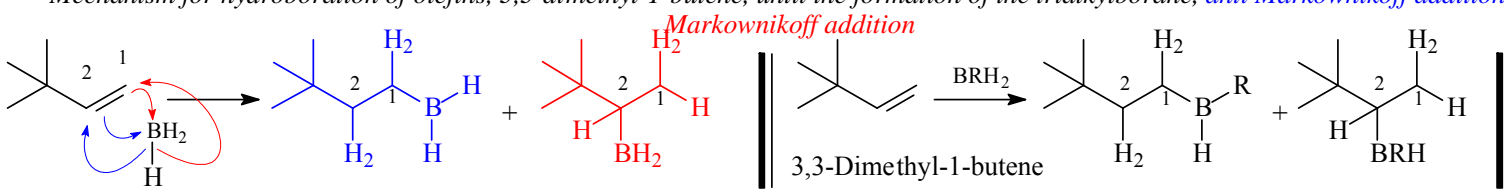

3,3-Dimethyl-1-butene

3,3-Dimethyl-1-butene
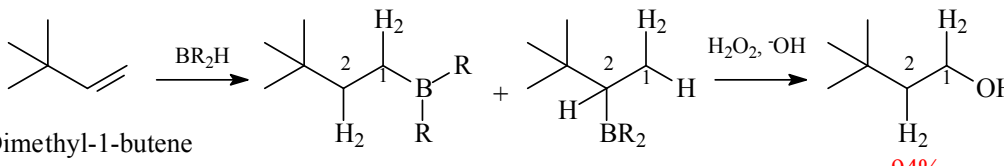

For the mechanistic explanations of oxidation of organoboranes by hydrogen peroxide, see Figure 7

Figure 9. Hydroboration of 3-methyl-1-butene and 3,3-dimethyl-1-butene until completion of reaction obtaining the corresponding trialkylborane, oxidation until obtaining of the corresponding alcohol [17]. Theoretical mechanistic views proposals by the authors 

Mechanism for hydroboration of olefins, 4,4-dimethyl-1-pentene, until the formation of the trialkylborane, anti Markownikoff addition and

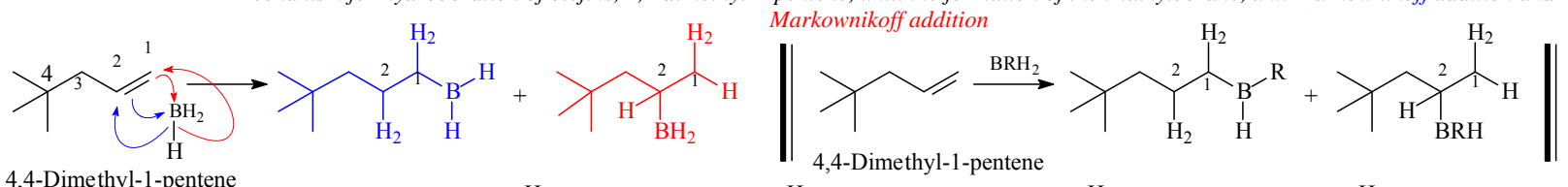

4,4-Dimethyl-1-pentene

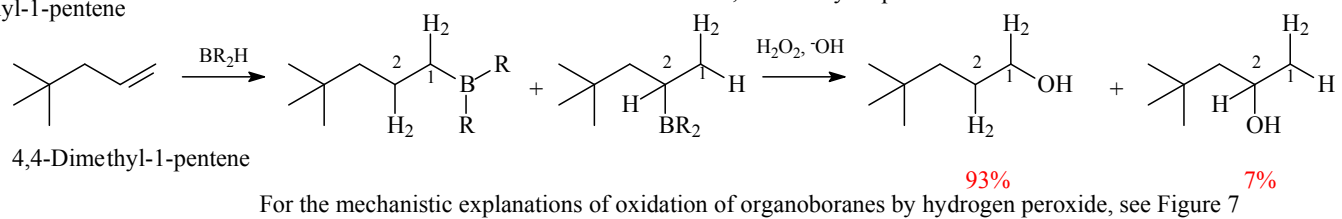

Figure 10. Hydroboration of 4,4-dimethyl-1-pentene until completion of reaction obtaining the corresponding trialkylborane, oxidation until obtaining of the corresponding alcohol [17]. Theoretical mechanistic views proposals by the authors

\section{Alkyl-disubstituted terminal olefins $\mathrm{R}_{2} \mathrm{C}=\mathrm{CH}_{2}$}

Here we are faced to two geminal alkyl groups, very hindering, by the way. This provides a terminal methylene of alkenic carbon easily approachable by voluminous groups like borane and its derivatives. The directive effect of the geminal alkyl groups (identical or not), is overpowering giving rise to boron-addition results almost exclusively on the terminal carbon. As a sample let us mention that 2-methyl-1-butene and borane give $99 \%$ of the primary alkylborane and $1 \%$ of the tertiary alkylborane, and 2,4,4-trimethyl-1-pentene [17] (Figure 11).

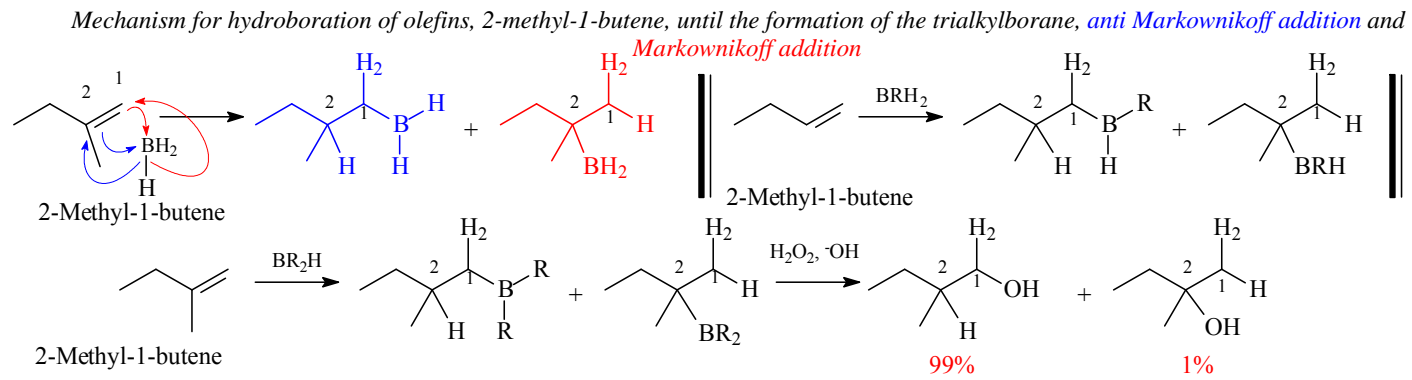

For the mechanistic explanations of oxidation of organoboranes by hydrogen peroxide, see Figure 7

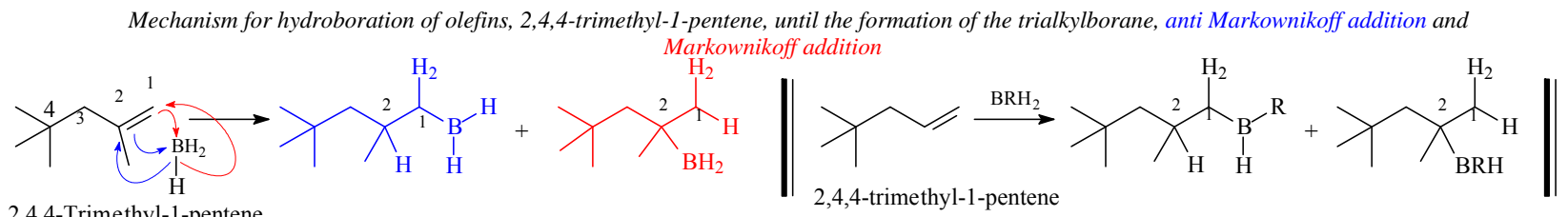

2,4,4-Trimethyl-1-pentene

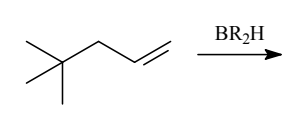<smiles>[R]B([R])C([2H])C(C)CC(C)(C)C</smiles><smiles>CC(C)(C)CC(C)(C)CCOO</smiles><smiles>CC(CO)CC(C)(C)C</smiles><smiles>CC(C)(C)CC(C)(C)O</smiles>

2,4,4-trimethyl-1-pentene

For the mechanistic explanations of oxidation of organoboranes by hydrogen peroxide, see Figure 7

Figure 11. Hydroboration of 2-methyl-1-butene and 2,4,4-trimethyl-1-pentene until completion of reaction obtaining the corresponding trialkylborane, oxidation until obtaining of the corresponding alcohol [17]. Theoretical mechanistic views proposals by the authors

\section{Alkyl-disubstituted internal olefins $R C H=C H R$}

The immediate examples for the approach to alkyl-disubstituted internal olefins are 2-pentene and 2-hexene, which experiment hydroboration with boron addition fairly equally distributed on both extremes of the double $\mathrm{C}=\mathrm{C}$ bond (Figures 12). The small difference in this distribution is observed in the geometrical isomers cis and trans. 
José A. Bravo et José L. Vila RBQ Vol. 37, No.1, pp. 46-63, 2020

Mechanism for hydroboration of olefins, cis-2-pentene, until the formation of the trialkylborane, anti Markownikoff addition and<smiles>[R]B([R])C([2H])(I)C(CC)CC(C)Br</smiles><smiles>[R16]C(CC)C(C)CCO</smiles><smiles>CCC(O)CI</smiles><smiles>CCC(O)C(I)CC</smiles>

cis-2-Pentene

For the mechanistic explanations of oxidation of organoboranes by hydrogen peroxide, see Figure 7

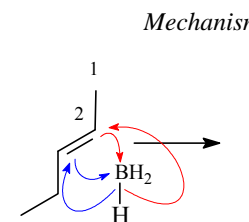
trans-2-Pentene

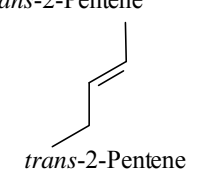<smiles>[R]B([R])C(I)C(CC)CC</smiles>

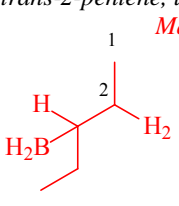
Markownikoff addition
Martil the formation of<smiles>CCC(I)CI</smiles>

$\overbrace{\substack{\mathrm{B}^{-} \\ \mathrm{R}^{-}}}^{\mathrm{R}}+$

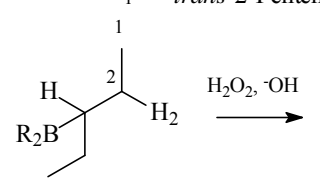<smiles></smiles><smiles>[R]P([2H])C(I)(I)C(CC)CC</smiles><smiles>CCC(O)CI</smiles>

$51 \%$<smiles>CCC(O)CI</smiles>

For the mechanistic explanations of oxidation of organoboranes by hydrogen peroxide, see Figure 7

Mechanism for hydroboration of olefins, cis-2-hexene, until the formation of the trialkylborane, anti Markownikoff addition and

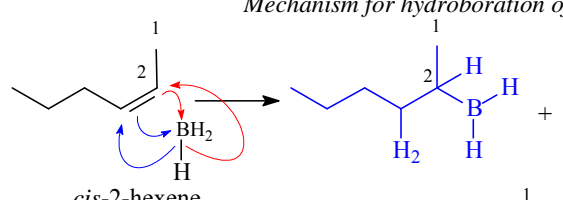

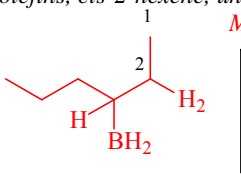

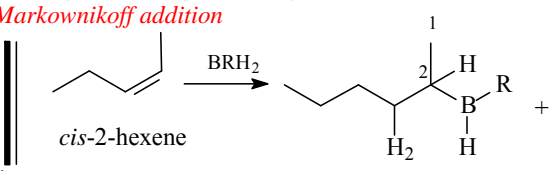<smiles>CCCC(Br)C(I)CC</smiles>

cis-2-hexene<smiles>C/C=C\CCC</smiles><smiles>[R]P([R])C([2H])(C)CCCC</smiles>

$\mathrm{H}_{\mathrm{BR}_{2}}^{2} \stackrel{\mathrm{H}_{2}}{\stackrel{\mathrm{H}_{2},-\mathrm{OH}}{\longrightarrow}}$<smiles>CCCC(O)C(O)I</smiles>

$50 \%$<smiles>CCCC(O)CI</smiles>

For the mechanistic explanations of oxidation of organoboranes by hydrogen peroxide, see Figure $7^{50 \%}$

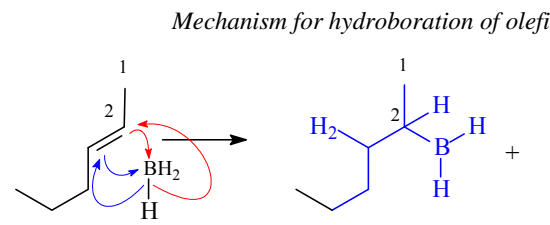

trans-2-hexene,

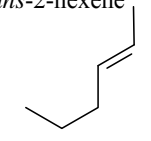

trans-2-hexene<smiles>[R]C([R])[C@@H](CCC)[C@H]([2H])I</smiles><smiles>[R]BC(I)(I)C(CCC)CCCC</smiles>

trans-2-hexene

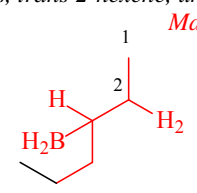<smiles>[R16]C(CCC)C(I)C(I)C(=O)O</smiles><smiles>CCCC(O)C(I)I</smiles>

$46 \%$<smiles>CCCC(O)CC</smiles>

Figure 12. Hydroboration of cis-2-pentene and trans-2-pentene and cis-2-hexene and trans-2-hexene until completion of reaction obtaining the corresponding trialkylborane, oxidation until obtaining of the corresponding alcohol [17]. Theoretical mechanistic Comments views proposals by the authors

A special case is the hydroboration-oxidation of cis-3-hexene [17], that gives a couple of enantiomeric alcohols after hydroboration and subsequent oxidation [17]. The distribution of boron on the double central $\mathrm{C}=\mathrm{C}$ bond is 
egalitarian (50:50). The result of hydroboration and hydrogen peroxide oxidation is the enantiomer couple: $(R)-3-$ hexanol and (S)-3-hexanol, as a racemic mixture (50:50). The mechanism for the hydroboration-oxidation of cis-3hexene is proposed in Figure 13. In this figure it is clearly established that, being cis-3-hexene a symmetric molecule, the alkyl side chains at each side of the double bond are identical. This means that there is no preference of the electrophile for either of the unsaturated carbons, giving a 1:1 distribution of borane. The article under current scrutiny and review [17] shows in Table IV the product of the hydroboration-oxidation of cis-3-hexene as an only product $(100 \%)$ in the column of 3 -ol result. This report is not specific, meaning by this that the only product is the 3-hexanol. However, Figure 13 clearly shows the formation of a racemic mixture. Figure 14 shows through molecular models the substrate structure, cis-3-hexene, and, the monoalkylboranes, product of the electrophilic addition, (S)-3-dihidroborohexane (1) and (R)-3-dihidroborohexane (2). Figure 15 shows the two enantiomers as specular images, demonstrating that the hydroboration gave two products instead of only one, as Table IV [17] seems to suggest.

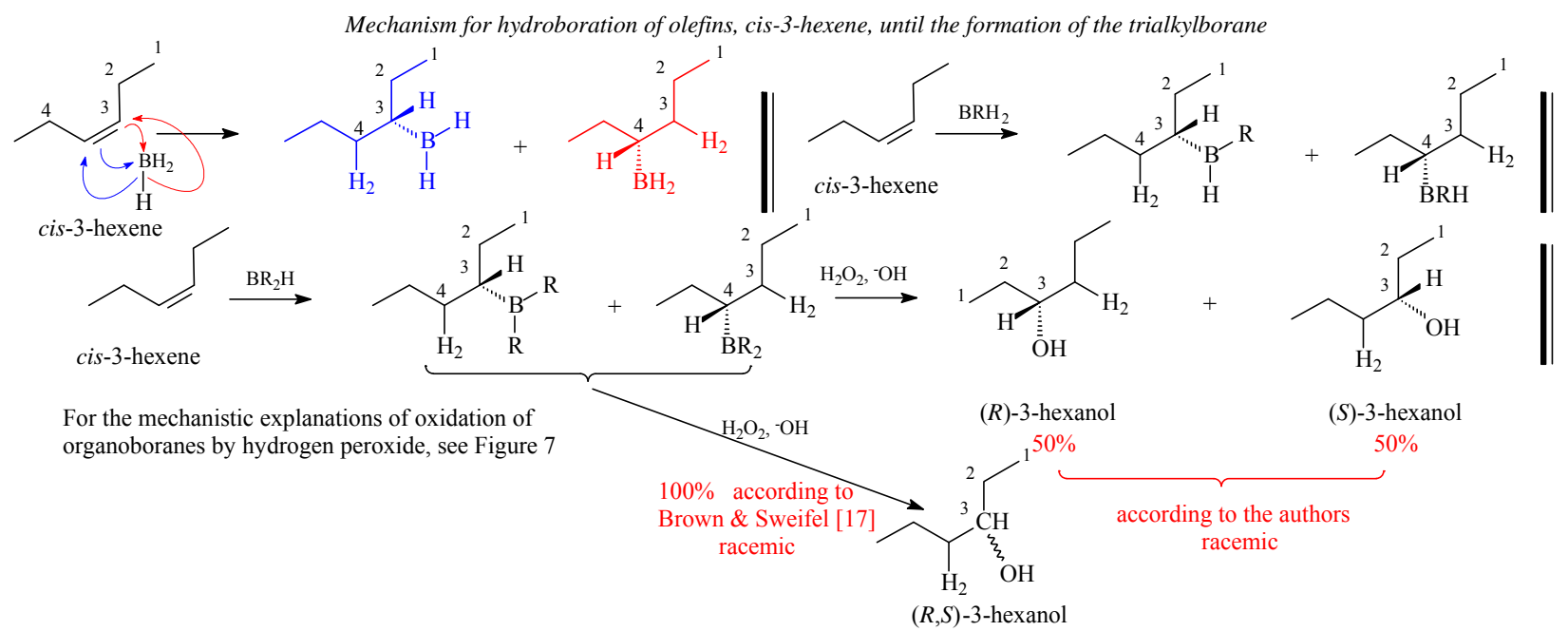

Figure 13. Hydroboration of cis-3-hexene until completion of reaction obtaining the corresponding trialkylborane, oxidation until obtaining of the corresponding alcohol [17]. Theoretical mechanistic views proposals by the authors

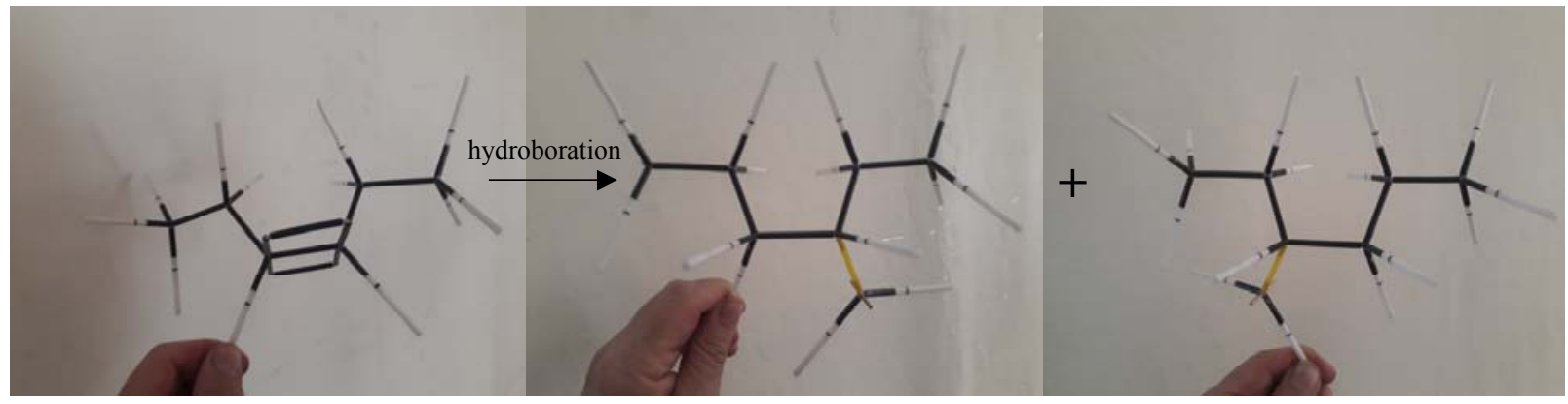

Cis-3-hexene

(S)-3-dihidroborohexane (1)

(R)-3-dihidroborohexane (2)

Figure 14. Hydroboration of cis-3-hexene to afford (S)-3-dihidroborohexane and (R)-3-dihidroborohexane

This analysis of the hydroboration of cis-3-hexene to afford a couple of enantiomers (S)-3-dihiroborohexane (1) (R)-3-dihidroborohexane (2) as a racemic mixture as shown in Figures 14 and 15 demonstrates existence of the transition state that directs a syn (cis) simultaneous addition of the $\mathrm{H}-\mathrm{B}$ bond to the double bond. If the addition were anti (trans), it means in two instead of an only step, then the two addition-products or the 3-dihidroboranes, would be diastereomers, and not enantiomers as it's the case. 

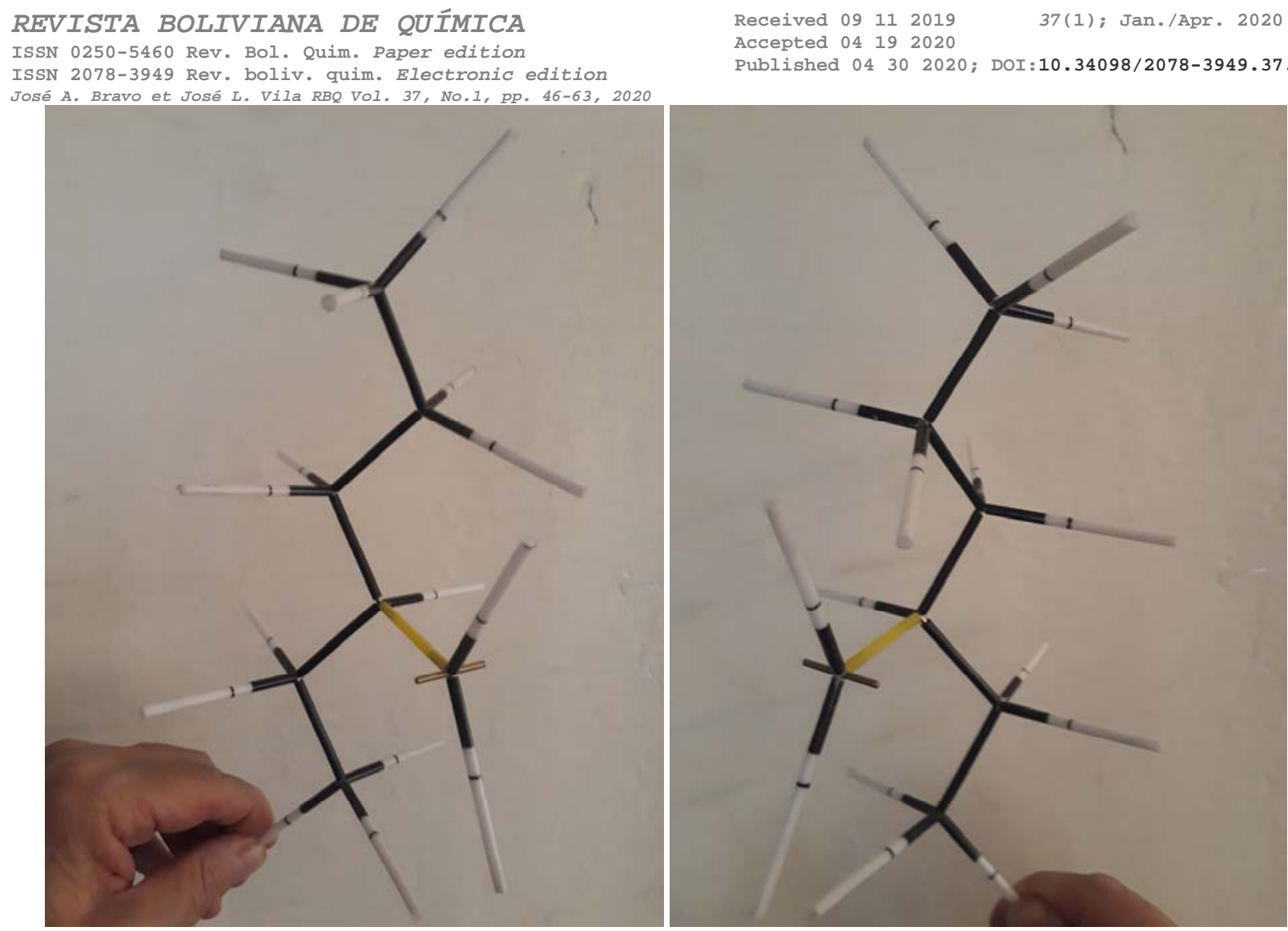

(S)-3-dihidroborohexane (1)

mirror

(R)-3-dihidroborohexane (2)

Figure 15. Enantiomeric products of hydroboration of cis-3-hexene, (S)-3-dihidroborohexane and (R)-3-dihidroborohexane as specular images

If the structural complexity at one of the side chains of the double bond is augmented, a small preference of the boron atom for the carbon atom with the less hindering side chain is manifested as shown for trans-4-methyl-2pentene (Figure 16) and trans-4,4-dimethyl-2-pentene (Figure 17). The reaction proceeds until the dialkylborane in the case of trans-4,4-dimethyl-2-pentene [17].
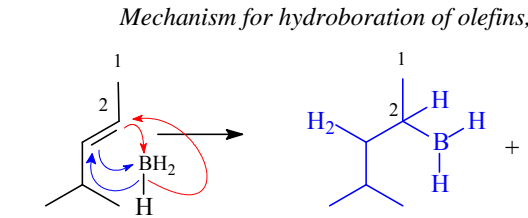

trans-4-methyl-2-Pentene
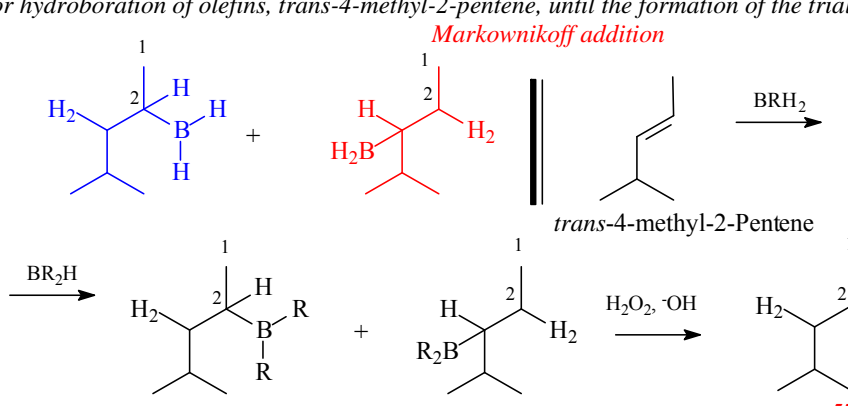<smiles>[R]B[C@@H](I)[C@@H](C)C(C)C</smiles>

trans-4-methyl-2-Pentene

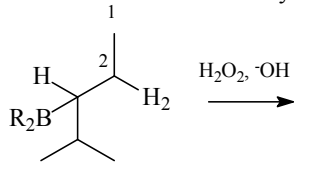<smiles>CC(C)C(O)CI</smiles>

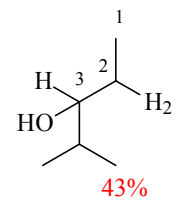

For the mechanistic explanations of oxidation of organoboranes by hydrogen peroxide, see Figure 7

Figure 16. Hydroboration of trans-4-methyl-2-pentene until completion of reaction obtaining the corresponding trialkylborane, oxidation until obtaining of the corresponding alcohol [17]. Theoretical mechanistic views proposals by the authors 
Mechanism for hydroboration of olefins, trans-4,4-dimethyl-2-pentene, until the formation of the trialkylborane, anti Markownikoff addition and
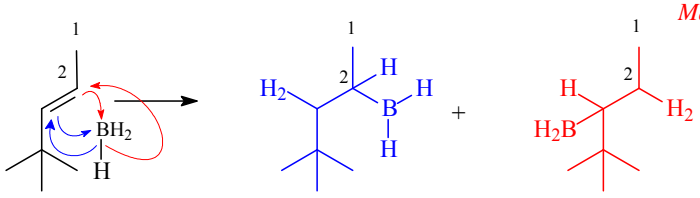
Markownikoff addition

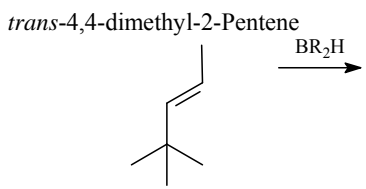

trans-4,4-dimethyl-2-Pentene
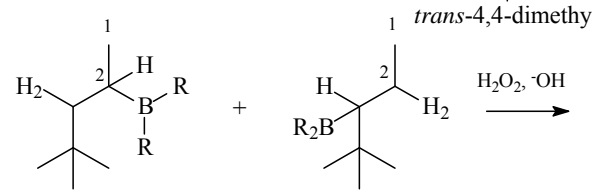

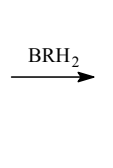

-Pentene ${ }_{1}$<smiles>[R]BC(I)C(C)(C)C</smiles><smiles>[B]C(C(I)C=C=C)C(C)(C)C</smiles>

For the mechanistic explanations of oxidation of organoboranes by hydrogen peroxide, see Figure 7

Figure 17. Hydroboration of trans-4,4-dimethyl-2-pentene until completion of reaction obtaining the corresponding dialkylborane, oxidation until obtaining of the corresponding alcohol [17]. Theoretical mechanistic views proposals by the authors

\section{Alkyl-trisubstituted olefins $\mathrm{R}_{2} \mathrm{CH}=\mathrm{CHR}$ '}

Two products were assayed as examples of hydroboration of alkyl-trisubstituted olefins, $\mathrm{R}_{2} \mathrm{CH}=\mathrm{CHR}$, 2-methyl-2butene with a $98 \%$ of accommodation of borane on the secondary unsaturated carbon and $2 \%$ on the tertiary carbon, and 2,4,4-trimethyl-2-pentene, which afforded the same distribution on the secondary and tertiary carbon as the 2methyl-2-butene. Both compounds under mild conditions reached until the second alkylation of borane only [17].

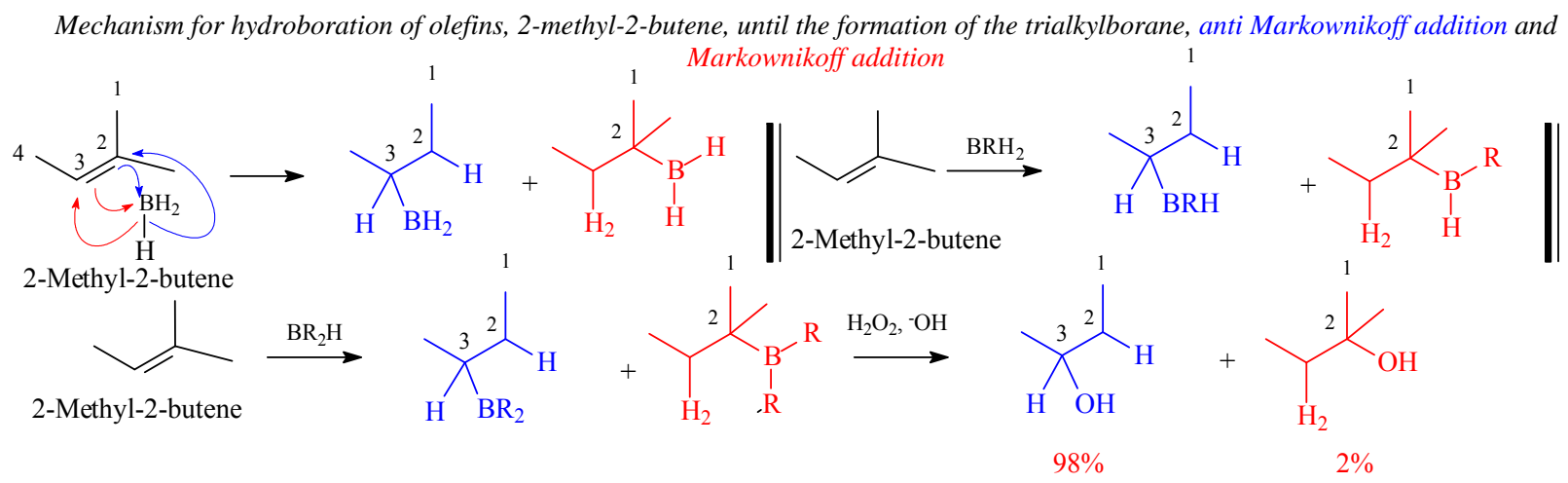

For the mechanistic explanations of oxidation of organoboranes by hydrogen peroxide, see Figure 7

Mechanism for hydroboration of olefins, 2,4,4-trimethyl-2-pentene, until the formation of the trialkylborane, anti Markownikoff addition and

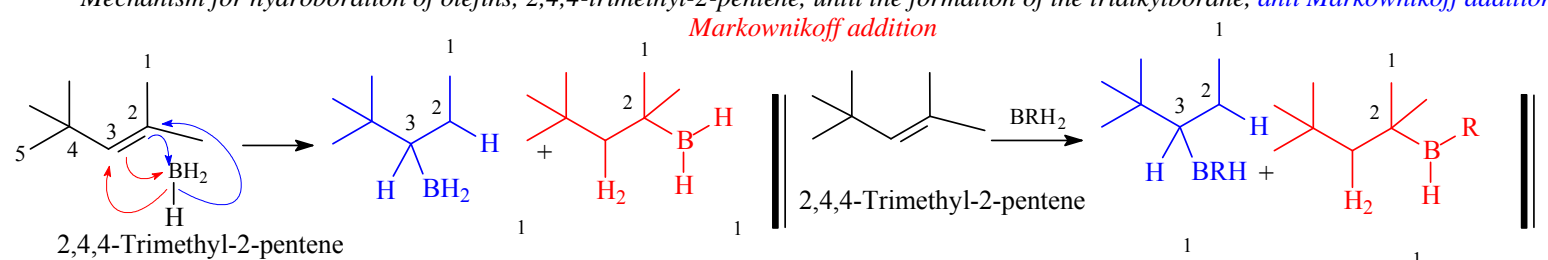

2,4,4-Trimethyl-2-pentene<smiles>CC(C)=CC(C)(C)C</smiles>

2,4,4-Trimethyl-2-pentene

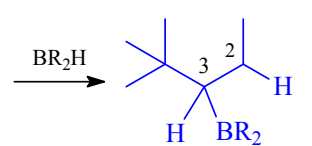

$\mathrm{H} \quad \mathrm{BR}_{2}$<smiles>[R]B(C)C(C)(C)C(C)C(C)(C)C</smiles><smiles>C1CCC1</smiles>
$\mathrm{H}_{2} \mathrm{O}_{2},{ }^{-} \mathrm{OH}$<smiles>[R16]C1CCCC1</smiles>

$98 \%$<smiles>CC(C)(F)CC(C)(C)I</smiles>

For the mechanistic explanations of oxidation of organoboranes by hydrogen peroxide, see Figure 7

Figure 18. Hydroboration of alkyl-trisubstituted olefins: 2-methyl-2-butene and 2,4,4-trimethyl-2-pentene until completion of reaction obtaining the corresponding dialkylborane, oxidation until obtaining of the corresponding alcohols [17]. Theoretical mechanistic views proposals by the authors 


\section{Hydroboration of aryl-substituted olefins}

Influence of the hydroboration (reducing) agent employed and temperature in the hydroboration of styrene

The use of one or another hydroboration agent makes no remarkable difference in the addition distribution of the couple $\mathrm{H}-\mathrm{B}$ on the double bond. Thence there was no significant change being noticed with the use of $\mathrm{LiBH}_{4}\left(\mathrm{Et}_{2} \mathrm{O}\right.$ THF or diglyme), $\mathrm{NaBH}_{4}$ (diglyme) or $\mathrm{B}_{2} \mathrm{H}_{6}$ (diglyme) [17]. A small increase in the proportion of addition on the $\alpha$ carbon of styrene was produced with increasing temperature [17].

\section{Styrene and its derivatives}

Styrene gives much different addition results of the hydroboration agent than those of alkyl-substituted olefins with proportions about $20 \%$ and $80 \%$ on the double bond [17]. See Figure 19 for a comparison of products in different solvents and by using different hydroboration agents and at different temperatures [17].
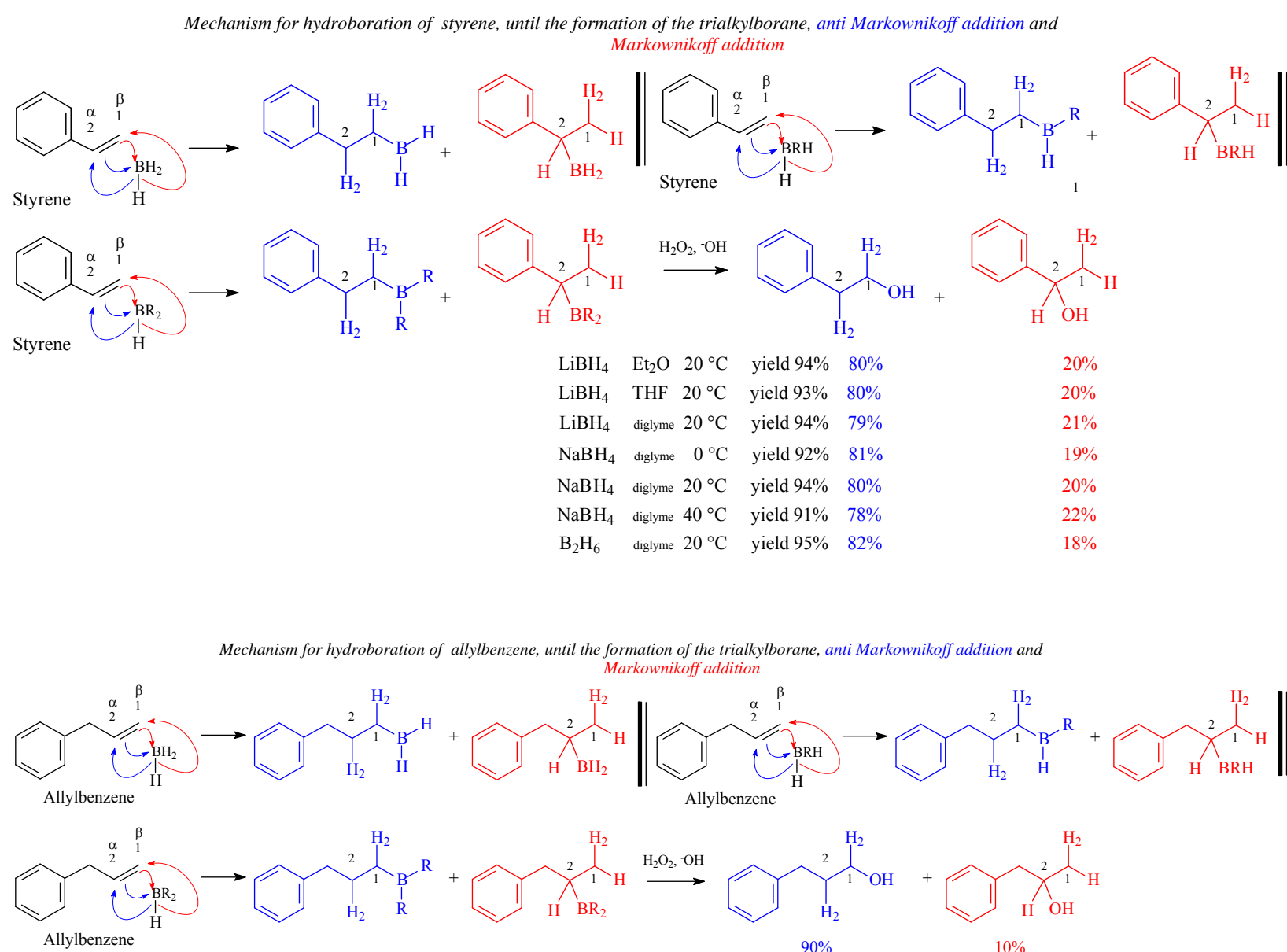

For the mechanistic explanations of oxidation of organoboranes by hydrogen peroxide, see Figure 7

Figure 19. Hydroboration of styrene and allylbenzene until completion of reaction obtaining the corresponding trialkylborane, oxidation until obtaining of the corresponding alcohols [17]. Theoretical mechanistic views proposals by the authors

As mentioned above, the distribution is $80 \%$ at $\mathrm{C}-1$ and $20 \%$ at $\mathrm{C}-2$ in the hydroboration of styrene. The effect of the phenyl group is minor but still present in allylbenzene with a $90_{\mathrm{C}-1}: 10_{\mathrm{C}-2}$ distribution [17], see Figure 19. The case of $\alpha$-methylstyrene shows the drastic directive effect giving a full regioselectivity with a100\% addition in position 1 [17]. See Figure 20. 


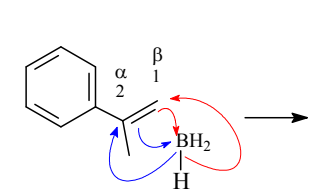

$\alpha$-methylstyrene

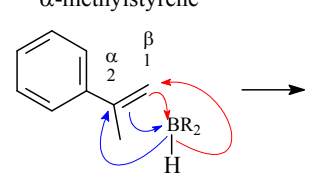

$\alpha$-methylstyrene

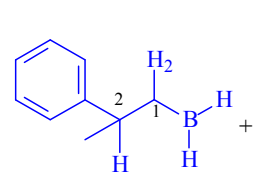<smiles>[R]B([R])C([R])C(C)c1ccccc1</smiles><smiles>CC(C)(C)C(C)(C)c1ccccc1</smiles>

$\alpha$-methylstyrene

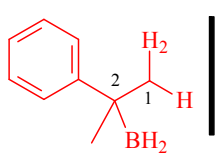<smiles>CCC[Pb]1(P)CCCCC1(C)c1ccccc1</smiles>

$\mathrm{H}_{2} \mathrm{O}_{2},-\mathrm{OH}$<smiles>[R]B([2H])C(C)C(C)c1ccccc1</smiles><smiles>C=CCC(C)(Br)c1ccccc1</smiles><smiles>CC(O)c1ccccc1</smiles>

For the mechanistic explanations of oxidation of organoboranes by hydrogen peroxide, see Figure 7

Figure 20. Hydroboration of $\alpha$-methylstyrene until completion of reaction obtaining the corresponding trialkylborane, oxidation until obtaining of the corresponding alcohols [17]. Full regioselectivity. Theoretical mechanistic views proposals by the authors

A comparison of the directive effect of alkyl-substituted (1-pentene) vs. aryl-substituted (styrene) olefins puts in evidence that the phenyl group of styrene is less effective than alkyl groups in directing the boron atom to the terminal carbon atom. This is seen in the hydroboration of trans-1-phenylpropene, with the competition between the methyl and the phenyl group [17], Figure 21.

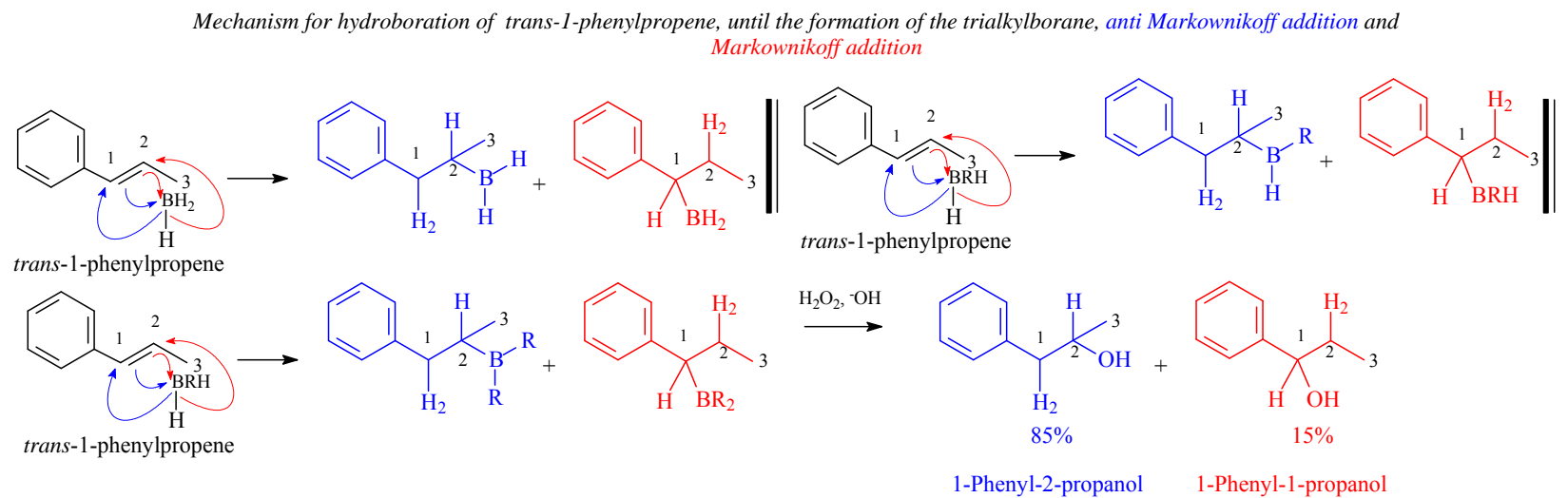

For the mechanistic explanations of oxidation of organoboranes by hydrogen peroxide, see Figure 7

Figure 21. Hydroboration of trans-1-phenylpropene until completion of reaction obtaining the corresponding trialkylborane, oxidation until obtaining of the corresponding alcohols [17]. Theoretical mechanistic views proposals by the authors

\section{Comments}

The article under current scrutiny [17], mentions a distribution of 15\% for 1-phenyl-2-propanol and $85 \%$ of 1 phenyl-1-propanol, however, Figure 21 demonstrates that the distribution is exactly the opposite, namely $15 \%$ for 1 phenyl-1-propanol and 85\% of 1-phenyl-2-propanol. This is an error of Brown and Zweifel [17].

\section{p-Substituted styrenes}

Due to the remarkable influence of the phenyl group in styrene on the tendency for the diborane when choosing a carbon atom over the other in the double bond, incited to the investigation of styrenes substituted in para [17]. This study was hoped to give enlightenment about the nature of the forces controlling the preference in the addition reaction. 
José A. Bravo et José L. Vila RBQ VoI. 37, No.1, pp. 46-63, 2020

The methyl substituent in styrene, provoked a minor effect, with a diminution from $20 \%$ in styrene in the $\alpha$ carbon to $18 \%$ in the para derivative. The methoxy substituent exerted a higher effect diminishing form $20 \%$ in the $\alpha$ position in styrene to $9 \%$ in the para derivative. Finally, the $p$-chloro substituent augments the distribution in the $\alpha$ position of the double bond until $35 \%$ from $20 \%$ in styrene [17], Figure 22.

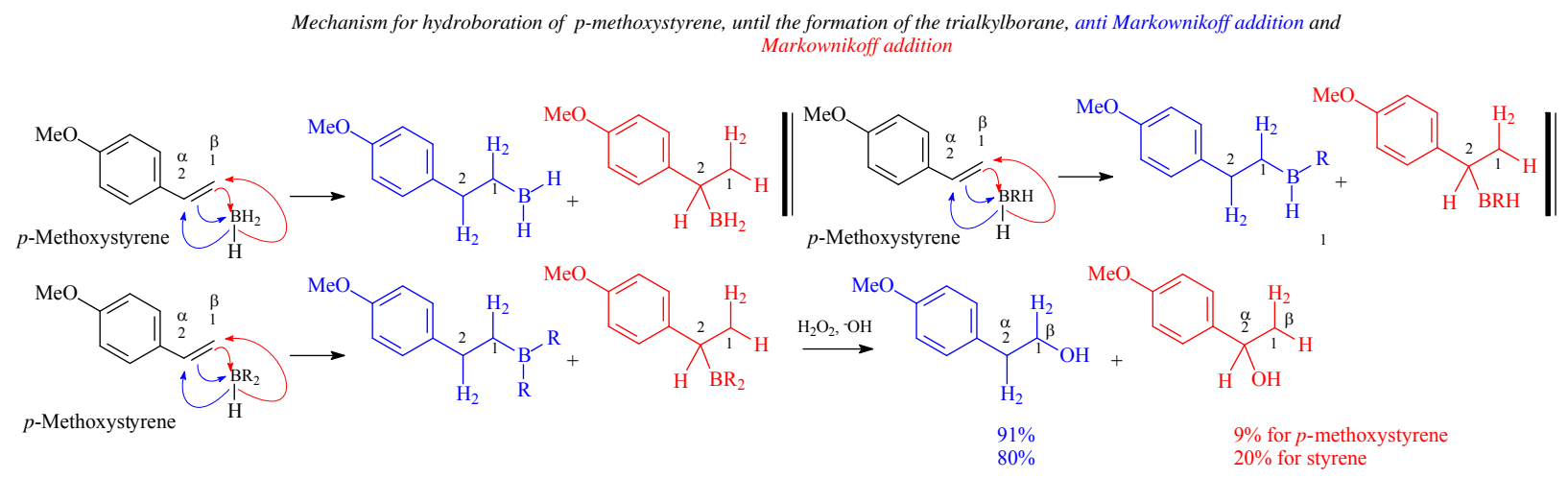

For the mechanistic explanations of oxidation of organoboranes by hydrogen peroxide, see Figure 7

Mechanism for hydroboration of p-methylstyrene, until the formation of the trialkylborane, anti Markownikoff addition and Markownikoff addition

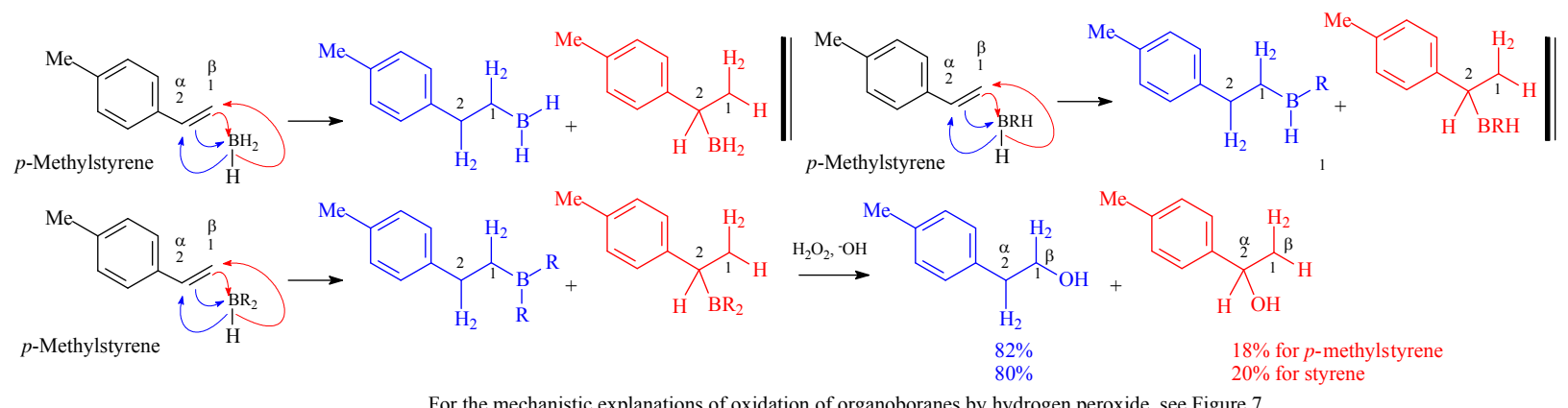

Mechanism for hydroboration of p-chlorostyrene, until the formation of the trialkylborane, anti Markownikoff addition and Markownikoff addition

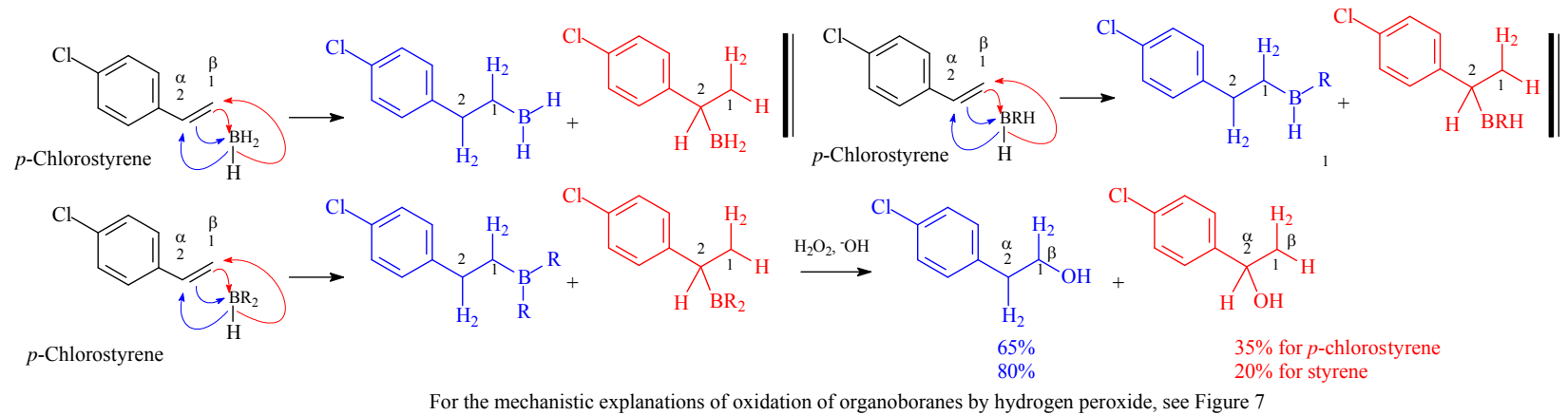

Figure 22. Hydroboration of p-methoxystyrene, p-methylstyrene and p-chlorostyrene in comparison to styrene, until completion of reaction obtaining the corresponding trialkylborane, oxidation until obtaining of the corresponding alcohols [17]. Theoretical mechanistic views proposals by the authors

\section{CONCLUSION}

The direction of addition of borane on olefins exposed in the examples above has been examined through the corresponding alcohols after oxidation [17]. The hydroboration repeats three times, each time with a new molecule 
ISSN 2078-3949 Rev boliv, quim. Electronic edition

José A. Bravo et José L. Vila RBQ VoI. 37, No.1, pp. 46-63, 2020

of substrate until reaching the trialkylated boron stage [17]. There is no evidence that the final distribution signaled by the alcohols is the same at each stage in the borane's alkylation pathway [17]. But, authors consider the distributions of the alcohols derived, as the same preferred by borane in the each of the preceding steps in the addition to olefins. Most of olefins proceeds to the trialkylborane $R_{3} B$ [17]. Other olefins, in function of the alkyl increasing structural complexity arrive to the dialkylborane stage or the monoalkylborane stage [17]. All that have been exposed until here, regards with the directive effects derived from steric effects on the direction of addition of borane on olefins [17]. However, authors signaled that steric directive effects are not alone in exerting influence in the addition of borane on olefins [17]. Some of them being much different in branching, but with similar effect in distribution in results of the electrophilic addition, as seen in the following table [17].

\begin{tabular}{lcc}
\hline \multicolumn{1}{c}{$\mathbf{R C H}=\mathbf{C H}_{2}$} & Terminal C & Internal C \\
\hline $\mathrm{R}=$ ethyl & $93 \%$ & $7 \%$ \\
$\mathrm{R}=$ isopropyl & $94 \%$ & $6 \%$ \\
$\mathrm{R}=$ t-butyl & $94 \%$ & $6 \%$ \\
neopentylethylene & $93 \%$ & $7 \%$ \\
\hline \multicolumn{1}{c}{ RCH=CHCH } & R-terminal & $\mathbf{C H C H}_{3}$ \\
\hline $\mathrm{R}=$ ethyl & $51 \%$ & $49 \%$ \\
$\mathrm{R}=$ isopropyl & $57 \%$ & $43 \%$ \\
$\mathrm{R}=$ t-butyl & $58 \%$ & $42 \%$ \\
\hline
\end{tabular}

All data collected and its previous analyses require an explanation other than the steric effects, and it concerns the electronic influences clearly playing an important role in controlling the direction of addition of the B-H bond to the double bond [17].

As shown above (figures 3 and 4), the addition of diborane to olefins happens clearly in a cis manner (see also figures 13-15), involving a four-center transition state [17]. The B-H bond is polarized with the hydrogen possessing a hydride character. Hence, by analogy, the electronic shifts are like in the addition of $\mathrm{H}-\mathrm{Cl}$ to double bonds. See Figure 23, where borane adds to propylene, that kind of electronic shift is the explanation for the addition of boron to the terminal carbon. The same explanation is applicable to 2,2-dialkylethylenes $(99 \% \mathrm{C}-1)$ and for the secondary position in trisubstituted olefins (98\%).
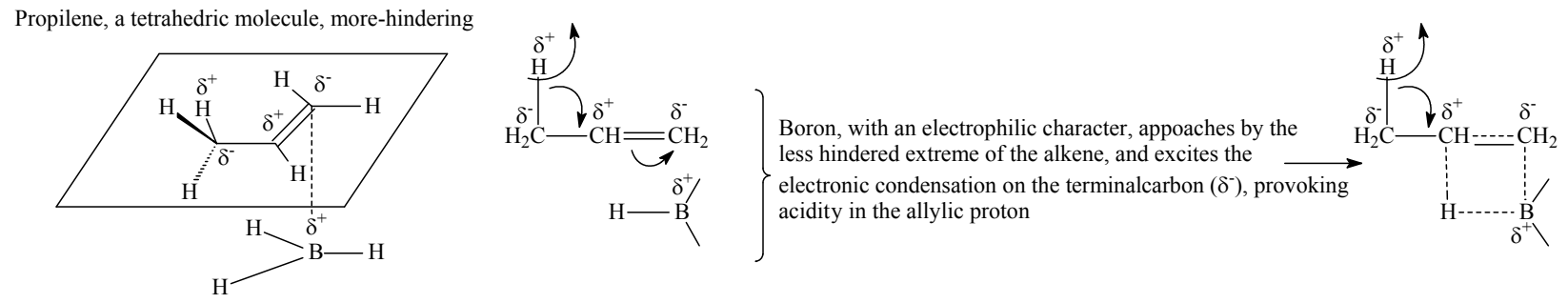

Figure 23. Hydroboration of propylene, electronic influences clearly playing an important role in controlling the direction of addition of the B-H bond to the double bond [17].

A similar approach can be employed for styrene to explain the preference of the boron atom for the ending position in the side chain. This approach also let explain the higher preference of C-2 with respect of the similar carbon in alkyl-substituted olefins: "In order to account for the enhanced substitution which occurs in the $\alpha$-position, we must recognize that the phenyl group can also stabilize a negative charge in the $\alpha$-position as in the benzyl anion. This transition state would be stabilized by an electron-withdrawing substituent, such as $p$-chloro-, and rendered less stable by an electron supplying substituent, such as p-methoxy" [17]. See Figure 24 . The transition state at $80 \%$ possesses three resonant structures (two of them corresponding to benzene), in contrast to transition state at $20 \%$ that dispose of only 2 resonant structures (corresponding to benzene), being thus less stable. 

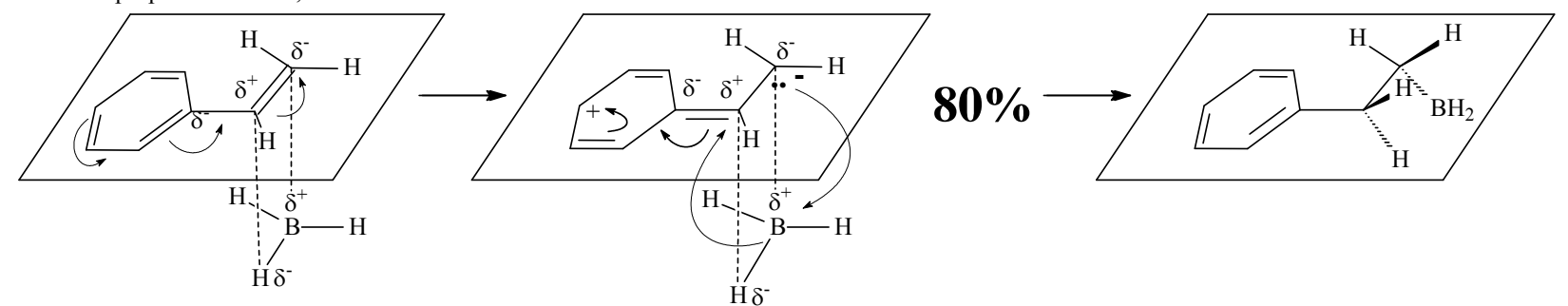

$80 \%$ approximation of borane (electrophile) to $\mathrm{C}-1$ provoking electronic concentration on $\mathrm{C}-1$ and on the $\mathrm{C}-1$ ' of phenyl, and provoking an electronic deficit on C-2. The phenyl group, rich in electrons is able to stabilize the transition state as shown above

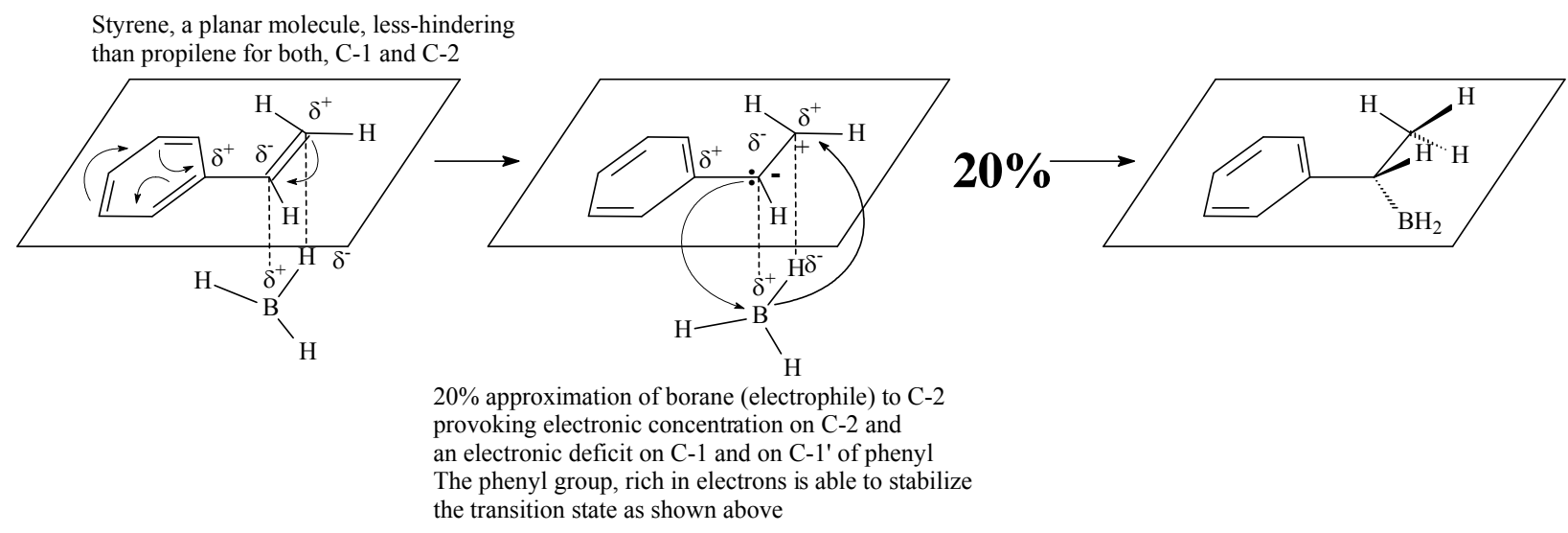

Figure 24. Hydroboration of styrene, electronic influences clearly playing an important role in controlling the direction of addition of the B-H bond to the double bond [17].

\section{REFERENCES}

1. Bravo, J. 2005, The organic chemistry notebook series, a didactical approach. Theoretical mechanistic approach to diasteroselective synthesis of cis-1,2-dialkenylcyclopropanols and subsequent oxy-Cope rearrangement by Jin Kun Cha et al, Rev. Bol. Quim., 23 (1), 1-10.

2. Bravo, J.A., Mollinedo, P., Peñarrieta, J.M., Vila, J.L. 2013, Mechanistic views of intramolecular hydroxycyclopropanation of $\omega$-vinyl carboxylic esters, Rev. Bol. Quim., 30 (1), 24-41.

3. Bravo, J.A., Vila, J.L. 2014, Mechanistic views of stereoselective synthesis of tri and tetra-substituted alkenes, part I; the organic chemistry notebook series, a didactical approach, $n^{\circ} 3$. Rev. Bol. Quim., 31 (1), 61-67.

4. Bravo, J.A., Vila, J.L. 2015, Mechanistic views of stereoselective synthesis of tri and tetra-substituted alkenes, part II; the organic chemistry notebook series, a didactical approach, ${ }^{\circ}$ 4, Rev. Bol. Quim., 32 (1), 15-23.

5. Vila, J.L., Bravo, J.A. 2015, Synthesis of alkenes by fragmentation reactions; Mechanistic views; the organic chemistry notebook series, a didactical approach, $\mathrm{n}^{\circ}$ 5, Rev. Bol. Quim., 32 (2), 37-44.

6. Bravo, J.A., Vila, J.L. 2015, Synthesis of alkenes by oxidative decarboxylation of carboxylic acids; Mechanistic views; the organic chemistry notebook series, a didactical approach, nº 6, Rev. Bol. Quim., 32 (3), 45-52.

7. Bravo, J.A., Vila, J.L. 2015, Synthesis of alkenes from ketones via arylsulphonyl-hydrazones; mechanistic views; the organic chemistry notebook series, a didactical approach, ${ }^{\circ}$ 7, Rev. Bol. Quim., 32 (4), 82-89.

8. Bravo, J.A., Vila, J.L. 2015, Stereospecific synthesis of alkenes from 1,2-diols; mechanistic views; the organic chemistry notebook series, a didactical approach, $\mathrm{n}^{\circ}$ 8, Rev. Bol. Quim., 32 (5), 121-125.

9. Bravo, J.A., Vila, J.L. 2016, Synthesis of alkenes by Claisen rearrangement of allyl vinyl ethers, part I; mechanistic views; the organic chemistry notebook series, a didactical approach, nº, Rev. Bol. Quim., 33 (1), $27-33$.

10. Bravo, J.A., Vila, J.L. 2016, Synthesis of alkenes by Claisen rearrangement of allyl vinyl ethers, part II; mechanistic views; the organic chemistry notebook series, a didactical approach, $\mathrm{n}^{\circ}$ 10, Rev. Bol. Quim., 33 (2), 95-103.

11. Bravo, J.A., Vila, J.L. 2016, Synthesis of alkenes by Claisen rearrangement of allyl vinyl ethers, part III; mechanistic views; the organic chemistry notebook series, a didactical approach, $n^{\circ} 11$, Rev. Bol. Quim., 33 (3), 127-133. 
ISSN 2078-3949 Rev, boliv, quim. Electronic edition

José A. Bravo et José L. Vila RBQ Vol. 37, No.1, pp. 46-63, 2020

12. Bravo, J.A., Vila, J.L. 2017, Claisen rearrangement of allyl vinyl ethers to afford alkenes, part IV; mechanistic theoretical proposals; the organic chemistry notebook series, a didactical approach, n 12, Rev. Bol. Quim., 34 (2), $40-49$.

13. Bravo, J.A., Vila, J.L. 2017, Mechanistic theoretical proposals for: alkenes by claisen rearrangement of alfa-allylthio carbenes; aza-cope rearrangement of 4-butenyliminium ions; 2-substituted pyrrolidine derivatives; synthesis of perhydrogephyrotoxin, key step; part v; the organic chemistry notebook, n 13, Rev. Bol. Quim., 34 (5), 142-149.

14. Bravo, J.A., Vila, J.L. 2017, Obtaining of alkenes by reductive coupling of carbonylic compounds; synthesis of z,e-6-dodecene, syntheses of flexibilene and isocaryophyllene, mechanistic views; the organic chemistry notebook, $\mathrm{n}^{\mathrm{O}} 14$, Rev. Bol. Quim., 35 (3), 73-84.

15. Carey, F.A., Sundberg, R.J. Advanced Organic Chemistry, Part B: Reaction and Synthesis, Plenum Press, $3^{\text {rd }}$ ed., 1991, New York, U.S., pp. 200-205.

16. Zweifel, G., Brown, H.C. 1963, Hydration of olefins, dienes, and acetylenes via hydroboration, Org. React. of Chemistry, 13, 153.

17. Brown, H.C., Zweifel, G. 1960, Hydroboration. VII. Directive effects in the hydroboration of olefins, J. Am. Chem. Soc., 82(17), 4708-4712.

18. Brown, H.C., Knights, E.F., Scouten, C.G. 1974, Hydroboration. XXXVI. Direct route to 9-borabicyclo[3.3.1]nonane via the cyclic hydroboration of 1,5-cyclooctadiene. 9-Borabicyclo[3.3.1]nonane as a uniquely selective reagent for the hydroboration of olefins, J. Am. Chem. Soc.1974 96(25), 7765-7770.

19. Brown, H.C., Ravindran, N., Kulkarni, S.U. 1979, Hydroboration. 52. Monohaloborane-methyl sulfide adducts as new reagents for the hydroboration of alkenes. A convenient synthesis of dialkylhaloboranes and their derivatives for organic synthesis, J. Org. Chem., 44(14), 2417-2422.

20. Brown, H.C., Racherla, U.S. 1986, Hydroboration. 76. Revision of the regioselectivity of the hydroboration of alkenes with dihaloborane-dimethyl sulfide complexes, J. Org. Chem., 51(6), 895-897.

21. Brown, H.C., Sikorski, J.A., N., Kulkarni, S.U., Lee, H.D. 1980, Thexylchloroborane-methyl sulfide. A selective monohydroborating agent with exceptional regioselectivity, J. Org. Chem., 45(22), 4540-4542. 